London School of Hygiene and Tropical Medicine, NOVEMBER $6 \mathrm{TH}, 1943$

\title{
POST-WAR NUTRITIONAL RELIEF
}

\author{
Chairman, The Rt. Hon. Lord Horder
}

\section{Experiences of the Last War and Since. Current State of Nutrition in Occupied Europe and Elsewhere}

Professor J. R. Marrack (London Hospital, Whitechapel, London, E.1) The Last War

Inability to import food for direct human consumption from overseas accounted for only a small fraction of the deficiency of food in continental Europe at the end of 1918; the chief cause was that the continent produced much less food. Labour of men and animals was taken from the fields; fertilizers were scarce; the yield of vegetables, food and feeding stuffs fell; animals were killed off owing to lack of home grown and imported feeding stuffs and in order that more land might be cultivated for direct human consumption; fertility of the soil fell for want of manure. Wide areas on the eastern front had been fought over four times; retreating armies had stripped the country of all that they could carry; many of the peasants had fled, and came back when the fighting ended to farms covered with weeds and young birches.

The total production of cereals in continental Europe as a whole was reduced by one-third (Table 1). In Germany with her post-war frontiers

TABLE 1

Total Production and Supply of Cereals in Continental Europe AS PER CENT. OF THE AVERAGE IN 1909 to 1913

(League of Nations, 1943, 1)

\begin{tabular}{c|c|c}
\hline Year & Production & $\begin{array}{c}\text { Production plus import, } \\
\text { including relief }\end{array}$ \\
\hline I909-13 & 100 & 100 \\
1919 & 67 & 70 \\
1920 & 72 & 74 \\
1921 & 81 & 85 \\
1922 & 77 & 80 \\
1923 & 90 & 92 \\
1924 & 80 & 83 \\
\hline
\end{tabular}

the total grain crop even in 1921 was under two-thirds of that in 1913 (Kuczynski and Quante, 1926), and the average yearly wheat crops in post-war Hungary and Poland in 1919 to 1922 were only 61 and 43 per cent., respectively, of those in the same areas in 1909 to 1913 (Hevesy, 1940). The degree of reduction of livestock ranged from 14 per cent. in 
France (Surface, 1926) to over 70 per cent. in west Poland (Goode, 1920). The reduction of animal products was much greater than this as the animals were underfed. Carcass weights in Berlin in 1919 were only 53 per cent. of the pre-war weights (Starling, 1919); the milk supply of Germany was only 30 per cent. of what it had been before the war.

This deterioration could not be remedied in a year. Cereals did not rise to the pre-war level until after 1924 (Kuczynski and Quante, 1926); even in France the number of cattle was not restored until 1924 (Surface, 1926).

Peace was not declared until June, 1919, and recovery was delayed by many residues of war after the armistice was signed on 11th November, 1918. The blockade was continued against Poland, Czechoslovakia, Esthonia, Austria, Turkey, Bulgaria, Rumania and Yugoslavia until April, 1919, and against Germany to the end of June (League of Nations, $1943,1)$. While the blockade was maintained these countries were not free to trade even if they could. Many of the countries, other than the Western Allies and neutrals, were too impoverished to buy food; the instability of the exchanges made barter the only possible form of trade; new frontiers were drawn across natural trade routes; transport had broken down and each country was loath to allow its rolling stock to leave its territory; local fighting continued; in the summer of 1919 the Rumanians invaded Hungary and looted at the rate of 16 train loads a day, taking 230,000 tons of food (Goode, 1920). In this atmosphere of insecurity and war, countries had little hope of obtaining loans for trade in the usual way. Without special machinery to supply food, 160 million people were faced with great privation and even complete famine.

All supplies provided through such special machinery were classed as relief. Three-quarters of the total food supplied as relief during the whole 5 years up to 1924 (Table 2) was furnished during the armistice

TABLE 2

Total Food Supplied as Relief after November 11, 1918, in Thousands of TONS, AND INDIVIDUAL Items as PER CENT. OF TOTAL

(League of Nations, 1943, 2; Surface and Bland, 1931)

\begin{tabular}{|c|c|c|c|c|}
\hline Kind of food & $\begin{array}{l}\text { Armistice } \\
\text { period }\end{array}$ & $\begin{array}{l}\text { Reconstruction } \\
\text { period }\end{array}$ & Total & $\begin{array}{l}\text { Child feeding, } \\
\text { U.S.S.R. } \\
\text { excluded }\end{array}$ \\
\hline $\begin{array}{l}\text { Total food, } \\
\text { thousands of tons }\end{array}$ & 4776 & 1455 & 6231 & 262 \\
\hline \multicolumn{5}{|l|}{$\begin{array}{l}\text { Individual items, } \\
\text { per cent. }\end{array}$} \\
\hline Flour & $27 \cdot 8$ & $47 \cdot 4$ & $32 \cdot 5$ & $36 \cdot 5$ \\
\hline Grain & $37 \cdot 0$ & $26 \cdot \overline{8}$ & $34 \cdot 5$ & - \\
\hline Maize grits & - & $7 \cdot 4$ & $1 \cdot 6$ & $3 \cdot 1$ \\
\hline Rice & $3 \cdot 15$ & $3 \cdot 5$ & $3 \cdot 2$ & $10 \cdot 0$ \\
\hline Beans and peas. & $2 \cdot 45$ & $3 \cdot 0$ & $2 \cdot 6$ & $13 \cdot 1$ \\
\hline Pork products & $7 \cdot 3$ & 1.9 & $6 \cdot 0$ & $5 \cdot 3$ \\
\hline Milk & $2 \cdot 1$ & $7 \cdot 3$ & $3 \cdot 25$ & $20 \cdot 8$ \\
\hline Cocoa & $0 \cdot 1$ & 0.7 & $0 \cdot 2$ & $2 \cdot 2$ \\
\hline Sugar & $1 \cdot 2$ & $2 \cdot 6$ & $1 \cdot 5$ & $8 \cdot 0$ \\
\hline Miscellaneous & $7 \cdot 1$ & $0 \cdot 2$ & $5 \cdot 5$ & $0 \cdot 75$ \\
\hline Army foods & $11 \cdot 6$ & - & $8 \cdot 9$ & - \\
\hline
\end{tabular}


period (League of Nations, 1943, 2). Peace was concluded in June, I919, but commitments entered into before that date were not completed before September. Almost all this relief was obtained on special credits granted by governments, particularly that of the U.S.A., or paid for in cash by the governments of the recipient countries. In some countries, Czechoslovakia for example, it was distributed through the normal channels of trade, in the same way as supplies produced by our Food Controller are distributed in this country at present; in Poland it was distributed through local authorities and co-operatives (Goode, 1920). Relief during this period was sent to 21 countries with a population of 230 millions; some of these countries received only small amounts; nine, Austria, Czechoslovakia, Finland, Germany, Yugoslavia, Poland, Rumania, Belgium and northern France (still supplied by the Commission for Relief in Belgium), with a population of about 150 millions, received over 100,000 tons each (Surface and Bland, 1931).

After September 1919 official relief ended. Apart from 480,000 tons of flour sold on credit by the government of the U.S.A. to the governments of Armenia, Austria, Czechoslovakia, Hungary and Poland, and the relief sent to the U.S.S.R. during the famine period, relief was supplied mainly to children in the form of meals served in canteens. This was financed by charity.

\section{Quantity of Relief}

The total amount of food including relief imported into the countries other than the neutrals and Western Allies, that is, Germany, Austria, Czechoslovakia, Hungary, Yugoslavia, Bulgaria, Rumania, Greece, Finland, Esthonia, Latvia, Lithuania, and Poland, was considerably less during 1919 and 1920 than in 1913, although food production in these countries was reduced (Table 3). The total 4 million tons of flour and

TABLE 3

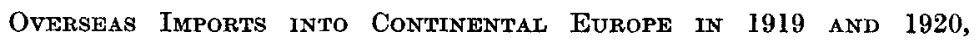
EXPRESSED AS PER CENT. OF THESE IMPORTS IN 1913

(League of Nations, 1943, 1)

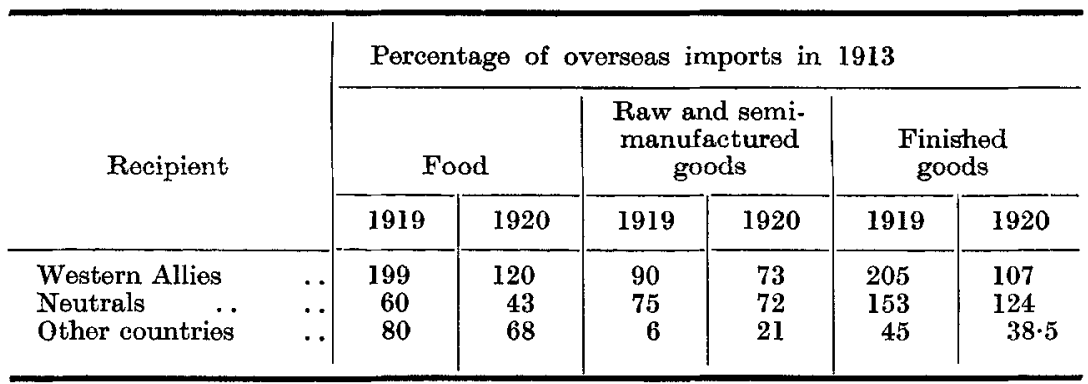

grain, supplied as relief, was not enough to make up the deficiency in wheat and rye in Germany alone. The total weight of food sent as relief to Poland, together with the average pre-war exports of wheat from this area was less than the average yearly deficit in wheat harvests in the years 1919 to 1921 .

voL. 2, 1944] 
In Charlottenburg the rations, which covered almost all food except green vegetables, from 28th April to 1st June 1919, after relief supplies to Germany had begun, supplied only 1671 Calories per head (Starling, 1919); just over one-sixth of the calories was derived from food supplied as relief; fats (butter, margarine and cooking fat) amounted to $3 \mathrm{oz}$. a week, bacon to $2 \cdot 6 \mathrm{oz}$. and meat to $7 \mathrm{oz}$.

In Vienna it had been possible to increase rations of flour, fat and bacon between January and August 1919, but after August rations (Table 4)

TABLE 4

Rations PER WeEk (Goode, 1920)

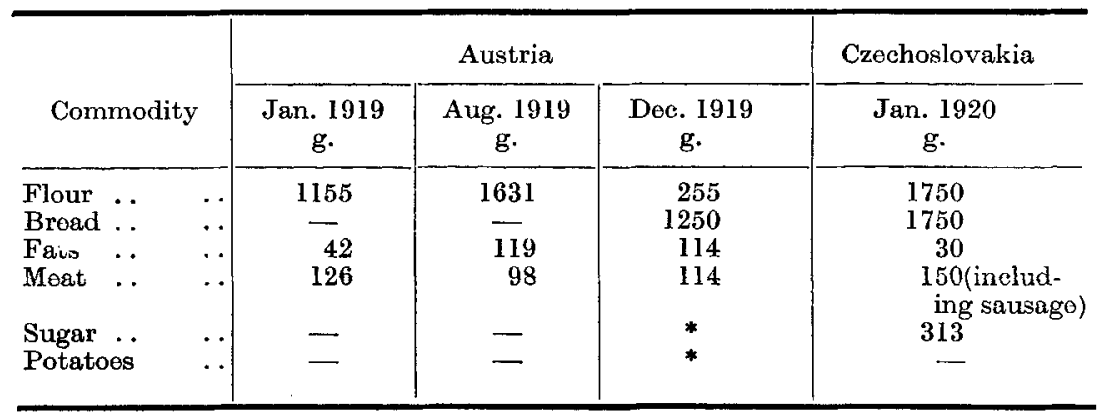

* Rationed but regular supplies could not be met.

were reduced (Goode, 1920). In 1920 Gribbon and Ferguson (1921) found that the diets of 49 families in Vienna supplied on the average per man value, 1860 Calories, $64 \mathrm{~g}$. total protein, $5 \cdot 3 \mathrm{~g}$. animal protein, and $40 \cdot 2 \mathrm{~g}$. fat (mainly margarine).

Only those children who showed signs of undernutrition were fed under the child feeding programme. At the peak periods in April in 1920 and in 1921,3 $3 \frac{1}{4}$ and $2 \frac{3}{4}$ million children, respectively, in Europe were being fed. It may be inferred that a large proportion of adults also were in need of more food.

It is obvious that, although the relicf appreciably reduced the suffering on the continent, the food supplied did not provide even sufficient calories and the provision of relief on a large scale ended too soon.

Quality of Relief

Flour and grain (Table 2) made up over 60 per cent. of the food supplied as relief during the armistice period. The next largest item was pork products, actually lard and some bacon; the amount of milk, evaporated and condensed, was small; some meat was included in miscellaneous and army foods which together made up some 9 per cent. of the total. As the supply of animal products in Europe was more deficient than that of cereals, the foods provided as relief were a poor supplement. The foods provided for feeding children during the reconstruction period (Table 5) still contained too little milk and no meat. Additional food provided by the recipient countries consisted mainly of flour and sugar. The actual meals in Austria (Hofmann, 1921; Kögler, 1921) and in Hungary (American Relief Administration, 1922) supplied daily only an average of $5 \mathrm{~g}$. of animal protein, the vitamin A and D contained in $70 \mathrm{ml}$. of milk (not 
TABLE 5

Children's Menus, Vienna (Hofmann, 1921)

\begin{tabular}{|c|c|c|c|c|c|c|c|}
\hline Day & \multicolumn{2}{|c|}{ Item } & Quantity, g. & Day & \multicolumn{2}{|c|}{ Item } & Quantity, g. \\
\hline Monday & $\begin{array}{l}\text { Rice } \\
\text { Sugar } \\
\text { Milk } \\
\text { Bread }\end{array}$ & $\begin{array}{l}\ldots \\
\cdots \\
\cdots\end{array}$ & $\begin{array}{c}60 \\
33 \cdot 3 \\
100 \\
75\end{array}$ & Thursday & $\begin{array}{l}\text { Bread } \\
\text { Sugar } \\
\text { Fat } \\
\text { Milk } \\
\text { Cocoa }\end{array}$ & $\begin{array}{l}\ldots \\
\ldots \\
\cdots\end{array}$ & $\begin{array}{r}108 \cdot 5 \\
58 \cdot 3 \\
6 \cdot 7 \\
46 \cdot 3 \\
6 \cdot 6\end{array}$ \\
\hline Tuesday & $\begin{array}{l}\text { Bread } \\
\text { Flour } \\
\text { Fat } \\
\text { Breado } \\
\text { Beans } \\
\text { Sugar }\end{array}$ & $\begin{array}{l}\ldots \\
\ddot{y} \\
\ddot{u b s} \\
\ldots\end{array}$ & $\begin{array}{c}65 \\
40 \\
13 \\
6 \\
80 \\
2 \cdot 7\end{array}$ & Friday & $\begin{array}{l}\text { Rice } \\
\text { Beans } \\
\text { Fat } \\
\text { Bread }\end{array}$ & $\begin{array}{l}\cdots \\
\ldots \\
\cdots \\
\ldots\end{array}$ & $\begin{array}{l}49 \cdot 0 \\
69 \cdot 5 \\
13 \cdot 0 \\
75 \cdot 0\end{array}$ \\
\hline Wednesday & $\begin{array}{l}\text { Rice } \\
\text { Fat } \\
\text { Milk } \\
\text { Sugar } \\
\text { Cocoa } \\
\text { Bread }\end{array}$ & $\begin{array}{l}\ldots \\
\ldots \\
\ldots \\
\ldots \\
\ldots\end{array}$ & $\begin{array}{c}61 \cdot 2 \\
6 \cdot 76 \\
30 \\
33 \cdot 3 \\
6 \cdot 6 \\
75\end{array}$ & Saturday & $\begin{array}{l}\text { Flour } \\
\text { Milk } \\
\text { Sugar } \\
\text { Fat }\end{array}$ & $\begin{array}{l}\cdots \\
\because \\
\cdots\end{array}$ & $\begin{array}{r}94 \cdot 8 \\
55 \cdot 0 \\
53 \cdot 0 \\
7 \cdot 5\end{array}$ \\
\hline
\end{tabular}

Daily average, $\mathrm{g}$.

\begin{tabular}{llll|lllr}
\hline Bread & $\ldots$ & $\ldots$ & 54 & Sugar & $\ldots$ & $\ldots$ & 24.9 \\
Flour & $\ldots$ & $\ldots$ & 21 & Cocoa & $\ldots$ & $\ldots$ & 2.2 \\
Milk (condensed) & $\ldots$ & 38.5 & Fat .. & $\ldots$ & $\ldots$ & 7.9 \\
Rice & $\ldots$ & $\ldots$ & 37.5 & Beans & $\ldots$ & $\ldots$ & 25.0
\end{tabular}

condensed or evaporated), and almost no vitamin C. These meals were planned on von Pirquet's system and all supplied a standard, carefully calculated meal of 660 Calories for children of school age; in Vienna and in Hungary the necessary calories were made up on Mondays and Thursdays by supplying bread with rice pudding. Hungarian children, at any rate, would not eat the bread. In lower Austria the rice pudding was supplemented with cocoa, which was more acceptable. In Hungary the children had never before eaten Boston baked beans, of which $76 \mathrm{~g}$. were served on Wednesdays and Saturdays, and would not eat them until they were cooked with a familiar sauce. Difficulties were increased in Hungary in 1921, when "the supervision of the kitchens and warehouses was organized in a different manner than in last year. High ranking retired army officers attended to the important work of control under the leadership of His Excellency General Barthelldy" (American Relief Administration, 1922); "theirs not to reason why."

It is illuminating to compare the amount of relief supplied, with certain other figures for food consumption. The total food supplied in relief in the 5 years 1919 to 1924 was less than the sum of imports of wheat and flour, meat, bacon and ham, and sugar, into the United Kingdom in the one year 1918, when our imports of food were cut to a minimum (Walworth 1940). The amount of pork products was under two-thirds of our imports in that year, and one-tenth of the total consumption of pork products in the U.S.A. in 1919 (Surface, 1926). The total condensed voL. 2, 1944] 
and evaporated milk supplied during 5 years was only half as large again as our import of condensed milk in 1918 (Beveridge, 1928), when our home supply of milk had fallen by only a quarter. It is evident that if food had been rationed in this country alone far more would have been available for relief. As it was, only surplus foods, particularly grain and pork products which the U.S.A. had been raising in large quantities to meet Allied demands during the war, could be obtained, and these foods were sent as relief, whether or not they met the physiological needs of the recipients.

Nothing has so far been said about famine relief in the U.S.S.R. in 1921-22. It gave an opportunity for a magnificent display of heroism. Many of those who went out died; over 3 million Russians also died of sheer starvation and many millions more of the indirect effects. This experience should not be an example of what we may expect but a warning of what will happen if we do not prepare in time or are half hearted when the time comes. It may be that at the end of the war large areas may be as destitute as the east of Poland was at the end of 1918 but, with modern transport, there should not be any difficulty in supplying it with food if stocks are ready. It is unfortunate that Dr. Melville Mackenzie (1942) has written of choosing which age groups of the population should be fed and which left to die, as if this choice were inevitable and not evidence of failure.

\section{The Present Position}

Over a large fraction of the European continent almost the whole of the food supply is rationed. From these rations we can estimate that the normal consumer is not getting more than 1400 Calories per head daily; the extra amounts allowed for heavy workers no more than balance their extra requirements. We may conolude that the average deficiency in Calories is about 600 per head daily. The degree of deficiency varies from Greece, Poland and Spain, where the daily Calories are under 1000, to Germany where they are about adequate. As a large number of livestock has been killed off including 10 million cattle a year ago, the deficiency of animal products, meat, milk, cheese and butter, is more serious than that of calories. The worst sufferers from this deficiency must be children over the age of 5, particularly adolescents, as the bulk of the milk supply is reserved for younger children.

The effects of these deficiencies are showing themselves particularly in the increased incidence of tuberculosis, the death rate from which in Belgium has risen as high as in 1918, and in the failure of children to increase in weight, even though they may be growing in height. Some cases of famine oedema have been reported in Belgium, but these may be mainly from concentration camps; low levels of plasma protein are, however, not common.

Vitamin deficiencies are not universal. It is said that rickets is now even less common than formerly in Belgium owing to the general distribution of vitamin D. Large amounts of potatoes are grown since this crop gives a high yield of calories per acre; as long as the supply is maintained gross scurvy is not likely to appear. Gross vitamin A defieiency is unlikely to occur in areas where margarine is fortified, as long as supplies of vitamin A hold out; difficulties of transport may limit the consumption 
of green vegetables and increase the risk of this deficiency. The use of flour of high degrees of extraction makes very gross deficiency of the vitamin B group unlikely except in maize eating areas.

The countries of the Far East, on the whole, exported considerable amounts of food. The chief food importing country was Japan. Scarcity of food in these areas is due to internal disorganization of production and distribution, comparable with that in Europe during and after the last war, but on a much larger scale. We know of famine in India now, due entirely to this disorganization. It is probable that the Japanese are, at present, stripping the occupied countries of stocks of food, although, owing to the great distances, they cannot be as thorough in this as the Germans are. We know that many millions of Chinese are almost completely without food. We may fear that, in the end, the scarcity of food will be more intense and extensive among the vast population of the Far East than in Europe.

\section{REFERENCES}

American Relief Administration, European Children's Fund in Hungary (1922). 2nd Report. Report of the Hungarian Committee. Budapest.

Beveridge, W. (1928). British Food Control. Oxford: University Press, p. 356. Goode, W. (1920). Economic Conditions in Central Europe (11). London: H.M.S.O.

Gribbon, M. R. and Ferguson, M. I. H. (1921). Lancet, 200, 474.

Hevesy, P. de (1940). World Wheat Planning. Oxford: University Press.

Hofmann, K. (1921). Die Amerikanische Kinderhilfsaktion in Wien. Vienna: Generalkommissariat der A.K.H.A., p. 113.

Kögler, H. (1921). Die Amerikanische Kinderhilfsaktion in Wien. Vienna: Generalkommissariat der A.K.H.A., p. 37.

Kuczynski, R. and Quante, P. (1926). Statistische Grundlagen zu Deutschlands Versorgung mit Nahrungs- und Futtermitteln. Berlin: J. Springer.

League of Nations $(1943,1)$. Europe's Overseas Needs, 1919-1920. League of Nations Publications. II. Economic and Financial, 1943, II. A.6. Geneva.

League of Nations (1943, 2). Relief Deliveries and Relief Loans, 1919-1923. League of Nations Publications. II. Economic and Financial. 1943, II. A.1. Geneva.

Mackenzie, M. D. (1942). Medical Relief in Europe. London: Royal Institute of International Affairs.

Starling, E. H. (1919). Report on Food Conditions in Germany. London: H.M.S.O.

Surface, F. M. (1926). American Pork Production in the World War and Reconstruction Period. Chicago and Now York: A. W. Shaw and Co.

Surface, F. M. and Bland, R. L. (1931). American Food Production in the World War and Reconstruction Period. Stanford: University Press.

Walworth, G. (1940). Feeding the Nation in Peace and War. Oxford: University Press.

\section{Discussion}

Dr. K. Evang (Royal Norwegian Ministry of Social Welfare, Kingston House, Prince's Gate, London, S.W.7), opener: Details and exact knowledge of conditions in occupied countries are rather scarce, and what facts there are, are to a large extent confidential. These remarks will, therefore, be along general lines.*

It is natural that our knowledge of the effects of faulty diet during the first World War is not particularly thorough. While the war lasted, very

* Most of the references have been taken from an article "Hvad Ernæringsforskningen kan lære oss" by O. G. Hansen in "Aktuelle Kostholds Spörsmal i Norge," 1939. Oslo: Statens Kostholdsnemd, pp. 207-232.

vox. 2,1944$]$ 
few people had time to make investigations in this field on a really scientific basis and, after the war was over, its problems were pushed into the background, together with the war itself. Such a tragedy must never happen again. Our knowledge is thus only sufficient to draw certain general conclusions such as Professor Marrack has presented to us.

It is not easy to express in exact figures the effects of malnutrition on health and life, because there are always so many other factors present. Nevertheless, the nutritional experience of the first World War was fairly straightforward because housing, sanitary, and such like conditions, were generally unchanged for the civilian population. It was only the diet which became worse little by little. It is different during this war.

The effects and scope of the malnutrition varied, of course, very much. It was partly a matter of a wrongly constituted diet and partly of insufficient quantities and, at times, of both combined. One factor found in many places was the decreased consumption of fats, to which many experts attributed a large part of the harmful effects on health and resistance. Characteristic in this respect is a survey of diet in Germany in 1917, showing an extremely low consumption of butter and edible fats, eighteen g. per man value per day, corresponding to about onethird to one-quarter of the normal consumption. Apart from this lack of fats, the diet in many places presented no remarkable differences compared with the diet which one may also find in normal times. It is not without reason that interest during the present war centres to a great extent also around the supplies of fat.

Of all forms of hunger, the eraving for fats probably causes the most violent suffering. Frithjof Nansen tells how, in crossing Greenland on skis, he and his companion Johansen had estimated for too low a supply of fats. Finally they ate the grease they had brought to kcep their boots soft and waterproof, despite the fact that they had plenty of other kinds of food such as biscuits and dried meat which did not, however, contain much fat.

Almost every author who describes nutritional conditions during the strict rationing of the first World War points out the destructive effects which malnutrition had on the general vitality and productive capacity of the population. The working capacity decreased seriously. Feebleness, lack of energy, and, what is particularly important during a war when great demands are made upon the morale, discouragement, spread. In a report on the effects of scarcity of foodstuffs, one of the leading German nutritionists, Rubner, wrote: "One could notice the physical breakdown in their appearance, in the sloppy clothes, in their complexion and facial expression. Weakness, fatigue after relatively slight efforts were the rule. Even their mental condition was characterized by inferiority, indolence, lack of initiative and desire for action."

Although this extremely important fact has been pointed out again and again also by modern experts, whose findings are based upon experience gained through diet surveys of recent years, it has not yet been accepted by general opinion. When it comes to food, the human being is still, to a high degree, considered as a machine, and not as a link in the social system. This has also greatly confused the general discussions in this country and in the United States of America on the question of supplying the starving European nations with food. It seems to have 
been forgotten that one of the conditions for future resistance agninst the conquerors and also for supporting the allied war aims in a broad sense, is mental and physical elasticity, a power of resistance which can be gained only through fair nutrition. A famished human being never revolts.

The younger generation suffered most. The development of children who were born or who grew up during the first World War was retarded. Even many years after their food had again become normal, one could see the effects of the malnutrition from which they had never completely recovered.

Among the neutral countries, Denmark, during the first World War, had especially significant experiences. The Danish farmer could sell his butter at a good price, while he and his children lived on a poor margarine and skimmed milk. The result was numerous eases of xerophthalmia due to the lack of vitamin A. When Denmark suffered export difficulties, and herself had to consume a great deal of her milk and butter, this sinister guest disappeared. The death rate of babies too showed obvious fluctuations with the changes in diet.

The changes in the death rate from pulmonary consumption were the most impressive. It increased in all countries subjected to strict rationing where there was also a lack of important foodstuffs. The death rate was greatest in those countries where, and at the time when, the food restrictions were most severe. The percentage increase in deaths from tuberculosis during the years 1914-18 was 61 in Germany, 44 in Italy, 35 in the Netherlands, and 15 in Great Britain.

Conditions were worst in cities where the supply of foodstuffs was most difficult. While in German cities death from tuberculosis among the female population increased by 91 per cent. from 1914 to 1918 , the increase in rural districts was 55 per cent. The average increase was 65 per cent. but "only" 23 per cent. in such typical agricultural states as Bavaria. A revealing survey in Vienna shows how scareity of food was translated into death from tuberculosis in various social classes. The increase in mortality was greatest in those sections inhabited chiefly by government officials and relatively well to do families. The reason is probably that the diet of the upper class was reduced to a much greater extent relatively than that of the poorer classes whose diet was already so poor that only moderate further restrictions were possible. A number of boarding schools, asylums and similar institutions suffered much under the reduced diet. In an English lunatic asylum the death rate from tuberculosis increased by no less than 210 per cent. during the years 1914-18.

In several respects the food situation on the European continent during this World War is different from that of the War of 1914-18.

(1) The food production on the Continent as a whole has not been cut down this time on a scale comparable with that during the first World War. In some countries it is, at least on a calorie basis, supposed to have increased.

(2) The area which the Germans dominate, and can utilize for their own food supply, is much greater and much richer. As a consequence, no expert with knowledge of food production in European

vor. 2,1944$]$ 
countries has ever insisted that it would be possible to weaken the enemy seriously by cutting down imports of foodstuffs into Europe so that the German peoplo would starve.

(3) A number of Allied Countries are occupied by the Germans, who thus have the opportunity to use the food, or rather the withholding of food, as a weapon against them. So far, the Germans do not seem to be following any uniform food policy, but have treated each country in a different way, according to the special circumstances of that country.

To express this in other words, the blockade of food as a weapon to win a war, I am not here giving any opinion as to the advisability of using such a weapon, which was the privilege of the Allied Powers during the last World War, is, during this war, being used by the Germans, perhaps with greater effect, and at least with greater flexibility.

This German economic warfare towards the occupied countries is rather shrewd and complicated. It does not, as many seem to believe, represent only looting. Quite a large exchange of food takes place between countries under German domination, controlled, of course, by the Germans, and always in their interest. The United Nations also have hampered movements of food inside the blockade to a great extent by agreements with neutrals and by control of currency.

This combined and very complex blockade policy has created, on the one hand, the serious food shortage in the different European countries, which you know so well and about which I am, therefore, not going into detail. On the other hand, this peculiar and most unhappy situation has created new problems of another type, political and psychological.

It is quite clear to me personally, and has been for some time, that, while a strict blockade was absolutely necessary during the first and very critical phases of this war, the strength of the United Nations is now so great as to allow us to adjust this mighty weapon to the new situation. $1 \mathrm{am}$ thinking in both military and hygienic terms.

There is reason to believe that during this war a great deal more research work is being done on the effect of malnutrition, hunger and starvation on a mass scale among people living under war conditions, in occupied and fighting countries, but most of the results will only be available after the war.

On the other hand, we can build upon the unprecedented advances in nutritional research and knowledge in the period between the two great wars, and there is no longer any discussion among nutritionists as to the deleterious, I should say destructive, effect of malnutrition and hunger on the human organism, especially the growing organism.

The modern point of view as to the relationship between food and health now includes three important concepts: There are certain deficiency diseases such as pellagra, beriberi and scurvy, where one or more specific factors are lacking in the diet. In other diseases, as for example tuberculosis, the diet is known to play a considerable part in the course of the disease and in the resistance to infection. Thirdly, there is the fact of general importance, that individuals having lived on a satisfactory dietary regime have a better chance than undernourished individuals to overcome almost all types of ailment. 
Professor Marrack stated that the average consumer in Europe does not at the present get more than 1400 Calories, and that, therefore, there is an average deficiency of about 600 Calories per head, per day.

Personally, I do not think that an individual can maintain his working capacity on 1400 Calories a day over a long period of time. Even if some are able to, I cannot agree to the adequacy of an additional 600 , giving a sort of minimum requirement of 2000 . I know that this figure has been adopted by the Leith-Ross Committee as an emergency figure for the first and most difficult period after the war, but I do not feel it is a happy choice. Personally, I believe that 2500 Calories would be a better figure. I should not be surprised if evidence gathered during the occupation in some countries would show deficiency symptoms on diets even higher in caloric content than that. On the whole it is my opinion that we are still on the low side in estimating optimum calorie requirements.

One still lacks, however, a single, easily recognizable criterion, a clinically observable sign, oceurring at the time when the individual passes into what, nutritionally speaking, might be called the danger zone. We still have to judge from the late and dramatic consequences of hunger, increased morbidity and mortality.

When intercurrent diseases and deaths occur, as is now the case in many occupied countries, we are already far beyond the direct effects of malnutrition. The damage which has then been inflicted is, in most cases, irreparable.

Even the real cause of the so called hunger oedema is as yet unknown. Is it due to a shortage of fat, to a bulky diet low in calories or to lack of animal protein? The last explanation, which scems to prevail in some circles, is certainly not supported by the experience gained in Norway during the occupation. There is there an increasing frequency of hunger oedema but, at the same time, lack of animal protein is not predominant. In some places, especially where fish is easily obtainable, there is on the contrary a rather high consumption of animal protein, up to 40 to $60 \mathrm{~g}$. per man value per day.

What is observed in the occupied countries today is first and foremost increased morbidity and mortality, decreasing weight, retarded growth of children, and deaths from all types of intercurrent disease. Deaths from real starvation also have begun to take place in some occupied countries. A matter of special concern is the feeding of so called "political prisoners," that means the thousands and thousands of allied comrades in arms, who are in the hands of the Gestapo. They are not regarded by the Germans nor, I am afraid, by the larger allied countries, as prisoners of war, and are therefore scarcely or not at all permitted to receive food parcels.

In planning to relieve the situation, it would of course be most satisfactory from the nutritional point of view to plan for the food to be'sent to the countries concerned in such a way that the population was put on an optimum diet, having regard also to the type of malnutrition from which it had been suffering. As far as shipment of food supplies during the war is concerned, this has so far not been possible. Only Greece has received any substantial food shipments through the blockade, and the type of shipments has been decided not so much from the point of view voL. 2, 1944] 
of nutrition as from that of economic warfare in the broadest sense of this term.

As far as one can see at the present the plans for feeding the occupied countries immediately after liberation suffer in much the same way. The main reason for this is, as you will all know, that it is supposed that there will be a world wide shortage of foodstuffs at the termination of hostilities.

In such circumstances there seems very little practical value in drawing up ideal, physiological standards for the food supply of libcrated countries. Even the method of starting from an optimum standard and making reductions according to the supposed world food supply situation was not accepted in the inter-allied committees working on these plans.

There are, on the other hand, certain practical principles which, in my opinion, are of value:

1. The people will ask for calories first. They have been underfed or starving, and they want to have their stomachs filled. As an example I mention that the Norwegian people, and the Norwegian nutrition experts agree about this; they do not first and foremost ask for protective foods or for vitamins, but for grain and fat.

2 . In the planning there is a strong tendency to treat every oountry in the same way. One wants to be "just." It is, however, very important to remember that one also has to consider the standard in the country before the liberation. It would obviously not be a fortunate solution from the nutritional or the psychological point of view, to bring a liberated nation rations which were lower than those which they had had during the occupation.

3. In the event of an Allied military invasion, the peoples of the occupied countries would certainly regard themselves as soldiers in the total war against the oppressors. Any attempt not to give them food good enough to bring them up to fighting capacity as quickly as possible, would not be understood.

4. Most of the occupied countries are now living from hand to mouth with small or no stocks. The small imports they have been relying upon, would, when once this military invasion takes place, be stopped. This means that immediate imports will be necessary to avoid catastrophe. The individual reserves and those of the families in most cases are also exhausted.

5. The peoples of occupied Europe have of necessity developed a "food mindedness" hitherto unknown. It really is a pity that circumstances do not permit us to utilize this fact to a greater extent.

6. Every effort must be made to increase the domestic food production as quickly as possible. For agricultural products, this will take some time, as Professor Marrack pointed out. Fish, that means animal protein and fat, can, however, be produced on an increased scale almost overnight if the necessary equipment is provided. In view of the fact that it is animal protein and fat that will be in such great demand, this point, in my opinion, cannot be stressed too strongly.

On the whole we must admit that the contributions of physiology, biochemistry and other branches of nutritional science are rather negligible for solving the problem of how to provide an adequate diet 
for the millions who have been undernourished for years. This problem will, unfortunately, be dominated by other considerations, such as available stocks, production capacity and transport facilities.

Our hope for the future is brighter. The Hot Springs Conference has created a magnificent possibility based on nutritional science and a nutritional conscience.

Dr. G. Bourne (University Laboratory of Physiology, Oxford): The degree of food deficiency in Europe depends mainly on the extent to which different countries were self sufficient in food before the war. Industrial countries get food sent from Germany or from other occupied countries to keep up production. Countries without industries have to do the best they can with the food they can produce.

The information which $I$ have been able to gather from various sources about the food situation in occupied Europe is as follows. It should be remembered that it applies on the whole to urban areas and that the distribution is usually uneven, poor people have difficulty in getting their rations, while the rich still get plenty through the black market.

Protectorate (Bohemia and Moravia): the daily intake of Calories was 3000 before the war with $80 \mathrm{~g}$. of protein; rations supplied 2300 in 1941 and 1900 in 1942 with $56 \mathrm{~g}$. of protein. Poland: the population of ten million people in the General Government receives only minute rations, Poles 700 Calories daily, Jews 400; the major part of the food is reserved for the Germans. The western part of Poland, which also contains ten million people, has been incorporated into the Reich. Norway: the situation has been discussed in detail by Dr. Evang. Denmark: rations supply only about 1400 Calories daily, but meat, fish, potatoes and other foods are unrationed, and the diet is as good as, if not a little better than, that of Germany. Holland: in 1942 rations supplied 1800 Calories; there was a 43 per cent. increase in the death rate of adolescents and a 31 per cent. increase in that of children under 4. Belgium: in 1942, 1000 Calories were derived from rations; there has probably since been a decrease. France: the situation in towns is sevore; rations supply little more than 1000 Calories, heavy workers get 1320 and very heavy workers 1450 , but their diets are probably supplemented by canteen meals. Germany withdraws from France 250 Calories daily per head of population. Yugoslavia: Croatia normally imported some food from Serbia; it now has to fend for itself, and rations supply 900 Calories and $30 \mathrm{~g}$. protein. In Serbia some 1200 Calories are obtained from rations. The diet is grossly deficient in minerals and vitamins. Greece: agricultural areas are limited and the country had only a 2 weeks' supply of food during the war, which was rapidly exhausted after the occupation. In November 1942 the bread ration was $47 \mathrm{oz}$. a week, flour and butter were unobtainable, and stewed carrots and turnips formed a usual dish. Deaths from starvation were numerous. In the early days of occupation some relief came from Turkey; more recently 15,000 tons of wheat a month, a present from Canada, have been carried in Swedish ships. The requirement is more like 50,000 tons.

In Germany the rations are still good, like ours.

In feeding Europe after the war the world shortage of fat will be one of the chief problems. It seems likely that the populations of occupied Europe are deficient in vitamins $A$ and $D$, riboflavin, calcium and possibly vor. 2, 1944] 
vitamin C. There are already reports of rickets, scurvy, failure of surgical wounds to heal, and fragility of bones; there is also evidence of widespread anaemia, particularly in Belgium.

Professor O. Kestner (School of Agriculture, Cambridge): Investigations in Germany in 1918-19 have shown that the excretion of nitrogen in the urine was only about $5 \mathrm{~g}$. in 24 hours. When animal protein equivalent to 3 to $4 \mathrm{~g}$. nitrogen was added to the diet it was completely retained, no excess appearing in the urine. Animal protein is of utmost importance in severe undernutrition.

\title{
Problems of Production in Relation to Post-War Nutritional Relief*
}

\author{
Dr. J. Hammond (School of Agriculture, Cambridge)
}

The extent to which post-war relief will be necessary and the rate at which it can be given, will vary in different countries according to circumstances. If one country is liberated at a time the supply position will be better than if all require relief at the same time. It will vary too, according to whether re-occupation is rapid, or time has been given for a scorched earth policy to be adopted by the retiring enemy. In all oases the supply position will be modified by the amount of shipping available. In planning relief, therefore, all these factors have to be taken into account and alternative plans made.

Because of the difficulties of supply the first phase of relief must be based on the minimum requirements necessary to maintain human life and health in all countries before any one country raises the standard of living to optimum requirements such as are envisaged in the second phase of reconstruction (United Nations Conference on Food and Agriculture, 1943). The minimum food requirements aimed at are those which exist under our rationing scheme here today, modified in accordance with the pre-war food conditions and habits of the country concerned. The minimum requirements for energy foods (calories) are as follows:

\begin{tabular}{|c|c|c|c|c|c|}
\hline \multirow{5}{*}{ Children: } & \multicolumn{3}{|c|}{ Population Category } & \multicolumn{2}{|c|}{$\begin{array}{c}\text { Average Calorie } \\
\text { Requirements }\end{array}$} \\
\hline & Under 1 year & . & .. & . & 900 \\
\hline & 1 to 3 years & .. & . & . & 1200 \\
\hline & 4 to 6 years & . & $\ldots$ & $\ldots$ & 1600 \\
\hline & 7 to 9 years & .. & . & $\cdots$ & 2000 \\
\hline & 10 to 12 years & . & . & $\cdots$ & 2500 \\
\hline \multirow{4}{*}{ Adolescents: } & : Boys 13 to 15 & years & $\ldots$ & $\ldots$ & 3200 \\
\hline & Girls 13 to 15 & years & .. & . & 2800 \\
\hline & Boys 16 to 20 & years & . & . & 3800 \\
\hline & Girls 16 to 20 & years & $\cdots$ & $\cdots$ & 2400 \\
\hline \multirow[t]{4}{*}{ Men: } & Sedentary & $\ldots$ & .. & $\cdots$ & 2500 \\
\hline & Moderately acti & & & $\cdot$ & 3000 \\
\hline & Active & .. & .. & . & 3600 \\
\hline & Heavy workers & . & $\cdots$ & . & 4200 \\
\hline \multirow[t]{4}{*}{ Women: } & Sedentary & $\therefore$ & $\cdots$ & $\cdots$ & 2100 \\
\hline & Moderately acti & ive & . & $\cdots$ & 2500 \\
\hline & Active & $\ldots$ & $\ldots$ & $\ldots$ & 3000 \\
\hline & Pregnant and $\mathrm{x}$ & nursi & & 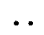 & 3000 \\
\hline
\end{tabular}

* Much of the information quoted in this paper is derived from documents circulated to Allied Governments but not published. 
The special minimum requirements of mothers and children for milk, which come second only to energy requirements, have been assessed at from $300 \mathrm{ml}$. daily for children from 14 to 21 years old to $800 \mathrm{ml}$. for those from 6 months to 3 years old and for expectant and nursing mothers. Allowance in estimates has been made for what was, and we hope still is, the higher proportion of children in the populations of eastern European countries.

The minimum yearly requirements for high class animal proteins can be supplied by the following:

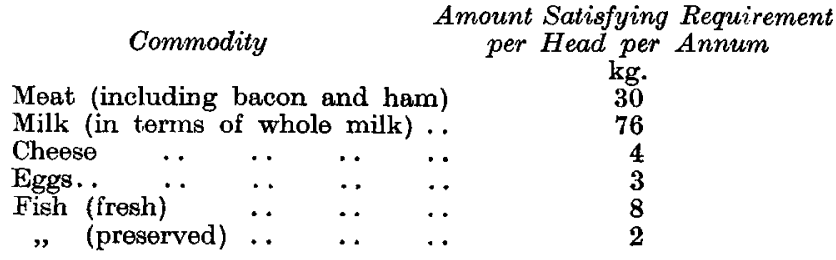

The level of consumption of animal proteins in southern and eastern Europe in pre-war days was, however, below this level so that it would not be necessary to supply all the meat in the early stages of relief, although it is to be hoped that it will be supplied in the period of reconstruction.

Owing to the higher standard of living in western Europe in pre-war days the produce of some 3 acres of land was required to feed a man for a year as compared with the produce of about 1 acre for eastern Europe. High levels of animal proteins in the diet entail this, for there is a loss in the conversion of plant into animal products; for example, it takes approximately 5 times as much land to produce 1000 Calories in the form of livestock products as in the form of potatoes or bread. This loss in conversion is higher for meat than for milk, and milk production rather than meat production must, therefore, take priority during the post-war relief period in Europe. It is perhaps not generally realized that Europe is almost as thickly populated as India, 74 persons per square kilometre as compared with 85 in India, so that there is need for intensive agriculture and a high output of food per square kilometre. The present food position varies considerably from country to country. In the production of energy foods, as compared with requirements, Greece, Finland, and Norway are probably in the worst position, since in these countries only a small proportion of the land is fit for arable cultivation.

\section{Means of Nutritional Relief}

The means to be taken to supply nutritional relief fall into two sections: (1) Production in the country concerned, that is, the restoration of its own agriculture. This is necessary not only to save transport, which may be a bottle neck, but also in order to get the economic life of the country going again. This will be of especial importance in the countries first liberated, at a time when transport will still be needed for war purposes. (2) Importation of food from overseas to supply the main deficiencies of a diet based on the products of local agriculture.

voL. 2, 1944] 


\section{Production in the Country Concerned}

The Hot Springs Conference (United Nations Conference on Food and Agriculture, 1943) emphasized the necessity for the production of energy foods first, since the danger from actual starvation is more important than the danger from deficiency diseases. This naturally has also been the war time policy in Europe. This policy in Nazi occupied Europe has entailed concentration on the growing of crops for direct human consumption rather than for animals, and a large destruction of livestock, the number of pigs and poultry being reduced by about 30 per cent. and of cattle and sheep by about 20 per cent. Nevertheless the actual production of crops has probably fallen by about 10 per cent. Allowance, however, should be made for the fact that now almost 100 per cent. of the cereals are milled for bread as compared with about 75 per cent. in pre-war years. Before the war, Nazi occupied Europe was about 93 per cent. self sufficient in energy foods, the balance being made up by imports. The necessity for maintaining and increasing the production of European agriculture is therefore evident.

The greatest amount of human food per acre is given by potatoes, wheat, alternatively rye on light acid soils, and sugar beet, and these crops must form the main basis of agriculture during the relief period. To increase yields per acre, which have fallen during the war, a supply of tractors and agricultural machinery for deep autumn ploughing is the first necessity to replace the shallow winter and spring ploughing with a depleted number of draft animals. Secondly, it will be necessary to provide fertilizers, phosphates, nitrogen and in some cases potash, where they are not available locally, for use on deficient soils. This will economize shipping space since their application results in the production of, on the average, three times their tonnage of extra food. Seeds will also be required, especially in the devastated areas. Since local varieties are usually best, it will be advisable in the case of cereals to supply imports for consumption, so that the grain of local varieties can be saved for seed. With potatoes, where a considerable tonnage is involved, movement from northern to southern Europe will be required to ensure maximum yields.

It is in regard to animal products, however, that the greatest deficiency, on the average about 25 per cent., occurs, and it is of these that the production will take the longest to recover. While by the second harvest after the re-occupation, crop production should be restored, it will probably take about 8 years before this is possible for animal production. Concentration on the restoration of dairy cattle will be the first requirement, because of the long time cattle take to reproduce and because they consume agricultural products, clovers and sugar beet by-products, not fit for direct human consumption, and also because of the necessity for a good local supply of milk to supplement a diet composed largely of cereals and potatoes.

The deficiency of some 11 millions of cattle in Nazi occupied Europe can gradually be made up by prohibiting the slaughter of all female cattle capable, or potentially capable, of breeding, by veterinary assistance in the treatment of cattle diseases and sterility, and by ensuring that the next generation of cattle are better milk producers than their dams by the widespread use of artificial insemination from good bulls. At a later 
stage of relief, it may be possible to import dairy cattle from North America, especially to devastated areas, in spite of the heavy demands that this makes on shipping. Extra feeding stuffs for dairy cattle should be available from the milling offals of imported cereals and these should increase the yield of milk per cow.

As soon as the calorie needs of the human population have been met, it will be possible rapidly to increase the output of meat and eggs by increasing the pig and poultry population; both species have a rapid rate of reproduction, but depend upon food which is suitable for direct human consumption.

\section{Importation of Food from Overseas to Supply the Main Deficiencies of a Diet Based on the Products of Local Agriculture}

The amount and sorts of food which require to be imported can be estimated from the difference between the estimated home production and the estimated consumption requirements. Naturally the requirements will vary in proportion to the destruction caused by the retreating enemy. Where this has been large, and especially in cities, energy foods, such as bread will be the first necessity. In the early stages of relief, condensed and dried milk for mothers and children will be of first importance, but in the later stages, local supplies of milk should be developed and the emphasis would be on imported supplies of meat. When the whole period of relief in Nazi occupied Europe is considered, the main need will be for meat and fats. Foods, which will store well and be convenient for transport will be a necessity.

Oil seeds from the tropies form the main source of supply for fats which are necessary to render carbohydrate foods palatable and reduce the bulk of the intake necessary to supply energy requirements. The oils should be imported as seeds, for the residues will, by providing extra feeding stuffs, increase the local supply of milk.

Meat, mainly in the dehydrated or canned form because of lack of refrigerator space, will not only be necessary in the early stages but also throughout the whole period of relief, in order to allow the dairy cattle recovery programme, with its prohibition of local slaughter, to proceed. It is easier to transport dehydrated meat than live animals for each of which a cargo space of about seven-eighths of a ton is required. It is very necessary that the overseas meat producing countries should now be accumulating additional reserve supplies of dehydrated and canned meat for this purpose.

There will probably be need for the supply also of some vitamins and minerals for a diet which has been predominantly cereal and lacking in animal products, although such deficiencies will probably occur only in certain areas and for certain classes of the community. Vitamin A, calcium and possibly vitamin $\mathrm{C}$ would appear most likely to be needed. As the milling percentage of cereals will be fixed at 85 per cent. or more, it is unlikely that vitamin $B_{1}$ will be required.

The Problem of Urban as Distinct from Rural Supplies is one which should be stressed. During the war, the urban areas have suffered much more from deficiencies in food supply than the rural areas. Steps are required to overcome this difficulty. For milk supplies, organization of transport to cities by the authorities, with a higher price for milk voL. 2, 1944] 
sold to go there will probably be necessary. The allocation to farmers producing milk for eities of rations of feeding stuffs, derived from imported cereals and oils seeds, would also facilitate supply to the urban areas.

The Machinery Necessary for the Planning and Carrying out of Nutritional Relief must necessarily be complicated. The Allied Post-War Requirements Bureau in London has defined the requirements for each country in detail and has given estimates for the production of foodstuffs within each occupied country. The body charged with acquiring and distributing supplies will be UNRRA, which will work in conjunction with national organizations. For relief to be effective it will be necessary for it to start during the period of military operations and this will be done by the military organization, AMGOT. At this time it will probably be necessary for observers to assess the more important needs and compare them with the estimated needs so that estimated priorities of supply can be confirmed, or changed if necessary.

The Problem of Permanent Reconstruction, as distinct from temporary nutritional relief, of giving optimum nutrition in place of a minimum level will demand a much higher efficiency in food production; to this end, the Hot Springs Conference (United Nations Conference on Food and Agriculture, 1943) is proposing to set up machinery for increasing and distributing knowledge in methods of food production in all countries.

In conclusion, it is necessary for us to realize what this programme of post-war nutritional relief in Europe will mean for us directly in this country. As far as British agriculture is concerned there will be need to continue, and if possible still further to increase, the high war time rate of production. Because of the need of cereals for human consumption in Europe and the Far East, imported concentrated animal feeding stuffs are likely to be in short supply for some years and it will be necessary to continue to depend largely on home grown feeding stuffs. With short supply of feeding stuffs it will be necessary to use those available most economically, that is, to produce milk in preference to meat where possible.

The large requirements of animal products for Europe in post-war years, together with the shortage of world supply and the time taken to reproduce the larger farm animals, will involve a delay in return to our pre-war levels of consumption of animal products. We should be prepared, therefore, for a prolongation of the period of rationing of these foods.

\section{REFHRENCE}

United Nations Conference on Food and Agriculture (1943). Final Act of the United Nations Conference on Food and Agriculture. [Cmd. 6451]. London: H.M.S.O.

\section{Discussion}

Miss M. Digby (Allied Post-War Requirements Bureau, Berkeley Square House, Berkeley Square, London, W.1), joint opener: Owing to the supply and shipping position, relief after this war is going to be a matter of applying limited resources in such a way as to secure the maximum result. Food supplies will have to be sent to meet the worst deficiencies, and the requirements of agriculture, seeds, machinery and fertilizers, 
distributed so as to secure the maximum return in increased production of food in Europe. This means organization. In one way we are in a better position than those who had to deal with the aftermath of the last war, since organization and control in agriculture have greatly increased throughout Europe, often in the form of co-operative movements which the farmers themselves have created and in which they have confidence. Where war time control is based on such pre-war national institutions, its continuance into the relief period will not be difficult. Where control was imposed for the first time by the enemy it will be violently unpopular and its continuance, though neoessary, will be much more unwelcome. In any case the whole system of producer control and consumer rationing will require modification so that it may answer to the needs of national welfare rather than of the German war machine, and may be adapted to an economy which is not forced to be self sufficient but which is able to avail itself of a measure of imports.

The use of institutions which he trusts and feels to be his own is one guarantee of collaboration from the farmer. The other is that there should be something tangible to offer him in exchange for his produce, not mere money which he cannot spend, perhaps in a currency he does not trust, but either consumer goods for his household or the means of production, which in turn will bring an increase in food supplies. If production can be organized on these lines it should be possible to produce first the emergency supplies needed to prevent starvation, and later that higher standard of nutrition to which the Hot Springs Conference, among other authorities, has looked forward.

In conclusion attention must be called to one problem of food organization which is of special and unique difficulty, the feeding of some 22 million people, deported workers, prisoners and refugees, who are not in their own homes, often not in their own countries, and unable to draw on any local supplies.

Dr. P. L. Yates (Ministry of Economic Warfare, Berkeley Square House, Berkeley Square, London, W.1), joint opener: Nutritionists have to will not only the end but also the means. In regard to relief they have to take interest in the control of the European producer and in the planning of increased food production overseas.

Since control of peasants in occupied Europe has in the main originated with the Nazis, we shall not be popular if we continue it. We can only succeed if we change the objectives, substituting reconstruction for requisitioning. We must demand the surrender of specified quantities from each farm but can perhaps link it with the supply of requisites. For instance a points system might be introduced, so many points being allotted for each bushel of wheat or gallon of milk surrendered, points which would be used by the peasant for the purchase of seeds, fertilizers and such like goods.

Nutritionists must also urge now an expansion of food production overseas. Lord Woolton has warned us of impending world changes. There is unlikely to be enough wheat to maintain current output of livestock products in North America and to cover Europe's relief needs in bread grain, unless by good fortune the 1944 harvest proves extremely favourable. 
In face of a world shortage of meat and fats certain nutritionists cast desperately about for substitutes. Some now proclaim that beans are as good as, and perhaps better than, meat. Would, however, the average European think so? Psychological considerations cannot be ignored, and, given present dietary habits, few would feel after a plate of beans the same satisfactions as after eating a beefsteak. One is reminded of the lines of G. K. Chesterton:

\section{"Unless you give him bacon You mustn't give him beans."}

Dr. A. Daniel (Cambridge, formerly Director of the State Agricultural Museum, Budapest): In view of the shortage of fats, oil seeds will be the key of speedy relief, as by growing them, fats may be produced in a comparatively short time. It should moreover be remembered that some of them, rape, oil flax and sunflower, may be grown in large parts of Europe.

Dr. W. R. Wooldridge (National Veterinary Medical Association of Great Britain and Ireland, 36 Gordon Square, London, W.C.1): A veterinary service capable of effecting the rapid control of major animal plagues such as rinderpest and bovine pleuropneumonia will be an essential element in the post-war organization to increase the production of milk and meat and to build up afresh a healthy livestock industry. If such diseases are reintroduced into Europe and left uncontrolled, animal productivity will collapse, since mortality in areas in which they are not endemic approaches 100 per cent.

\section{The Organization of Nutritional Relief in the Field}

\section{Dr. A. E. Russell (International Commission for War Refugees in Great Britain, 67 Brook Street, London, W.1)}

It is agreed that the problems of relief organization today are beyond the scope of voluntary bodies, but the experience gained by the personnel of voluntary bodies may be of value in building up the complicated schemes necessary in planning for the relief of post-war Europe. To summarize this experience it may be said that if relief is to be on a large scale it must be applied through the normal channels of trade; plans should be directed also towards initiating or strengthening permanent social services in the country concerned, and it is through these social services that records can be kept and opportunities for nutritional research arise.

Relief measures in the field should be operated as far as possible through the machinery of the local government of areas shown by the preliminary survey to be in greatest need, and should be carried out by trained organizers, whether native or foreign, who are capable of fostering and utilizing a spirit of independence and self help in the recipients of relief. In refugee camps and devastated areas where social organization does not exist, the relief administration should encourage the formation of a committee to take the place of local government, and a scheme of feeding priority groups through child welfare centres, maternity units, schools 
and workshops should be started as soon as possible. These first steps are the foundations on which all subsequent relief and reconstruction are based. The initial organization can make a refugee either into a helpless recipient of food and clothing, a true "victim" of relief, or into a self reliant, disciplined member of a naturally resurgent community. Refugees and homeless people are not helpless sheep, and it is a great mistake to enforce discipline without revealing plans and gaining their confidence.

Camps should not be too large; they should be for not more than 5000 persons and should be subdivided into sections of not more than 1000 persons, each administered by an elected committee of 10. Each section should be a self contained village community in its welfare services and community life and should have an elected representative on the central administrative committee. Loud speakers should be used to explain plans, to give information and counteract rumours, and to call up labour as it is needed.

A preliminary survey of the field should be made to determine the actual, as compared with the official, numbers of the population, the rations actually received, the local supplies available, the condition of fuel and transport, and the existence or lack of means of distribution. All these factors have to be investigated and if possible adjusted before the relief scheme can be put into operation. In making the survey, the markets or distribution centres should be visited and housewives questioned about the rations received. An inquiry should be made in house to house visits on a random basis, and by questioning persons waiting in food queues. Bakehouses should be visited and the actual constituents of the bread noted. Random samples of schoolchildren should be examined for signs of malnutrition and kept under observation as a measure of the success of the relief programme. Groups of persons suffering from special hardships should be sought out. For instance, in Spain during the Civil War, refugees on a money allowance were at a disadvantage as the local people refused to sell to them when food became scarce. The Government supplied them with the official ration in kind and, as the food scarcity increased, the refugees were better off than the civilian population who were dependent upon local markets.

Registration for relief ration cards should include details of identification and occupation, so that where social organization is lacking and the means of distribution do not exist, the available labour, clerks, office workers, retail and wholesale storekeepers, cooks, teachers, nurses, carpenters, dressmakers and so on, can be called up by loud speaker and used without delay in the relief scheme.

The registration card used in the Spanish relief was also a ration card valid for one month and was an abbreviated record of the holder's identity, occupation, and medical state. A similar type was used in the refugee camps in France and is now in use in the Greek refugee camps in the Middle East (Barratt-Brown, 1943; Friends' Ambulance Unit, 1944).

In Spain and France the International Commission for War Refugees took part in the following large scale feeding schemes, based mainly upon the provision of a supplementary ration of 50 to $100 \mathrm{~g}$. of dried whole or skimmed milk, and $150 \mathrm{~g}$. wholemeal flour made up into biscuits with $15 \mathrm{~g}$. peanut oil and dried skimmed milk according to supplies available, and $10 \mathrm{~g}$. cod liver oil, giving 500 to 1000 Calories according to age:

voc. 2, 1944] 
(1) Supplementing the rations of the static population, the families in their own homes, by issuing weekly packages of dried pulses, rice, sugar, tinned fish, and other commodities according to the supplies available.

(2) Feeding priority classes, children, adolescents and pregnant women, with additional rations of dried milk, cod liver oil and cereals through welfare centres, schools and hospitals. Other relief organizations provided supplementary rations for manual workers through factory canteens.

(3) Feeding refugees:

(a) On the road through mobile and fixed point canteens.

(b) In transit camps, by canteen feeding and a distribution of liquid milk for babies.

(c) In semi-permanent camps, by canteen feeding, by opening schools and providing a midday meal for children over 5 years, and by organizing milk kitchens for expectant mothers and children under 5 years.

(4) Organizing colonies for orphans and abandoned children.

By the autumn of 1938 the official rations in Republican Spain had fallen to just under 1000 Calories daily, and the bread ration had been fixed at $150 \mathrm{~g}$. The refugee population had risen to approximately two and a half millions, according to a report to the League of Nations (1938). Milk supplies were reserved for infants under 2 years who received 2 or 3 tins of sweetened, sometimes skimmed, condensed milk weekly. In Catalonia there was great scarcity of fats; about half a litre of olive oil was issued to each family about once a month.

Rickets, which is comparatively rare in Spain even in big cities, began to appear in a mild form in Barcelona in the late autumn of 1938. The incidence reported varied from 10 to 60 per cent. according to the district and the standards of the reporters. Famine oedema, characterized by a lard like pallor and puffiness of the eyelids, hands and legs, was seen amongst the children attending the breakfast canteens. Tomatoes and oranges were obtainable throughout the period in question and no cases of clinical scurvy were met with amongst the civilian population, although it was reported in the army and occurred later amongst the Spanish refugees in French concentration camps in the spring of 1939. The few cases of pellagra, 5 in all, met with casually in Catalonia where wheat imported from France is the staple cereal, all occurred in elderly refugees from Madrid and southern Spain.

Owing to the absence of medical personnel on military duty, and the lack of laboratory facilities and equipment, very little nutritional research appears to have been carried on during this time. In fact, in any country under these conditions, it would be essential to send a completely equipped and self contained research team if reliable results were to be obtained.

A joint plan of relief by most of the voluntary organizations enabled Barcelona City Welfare Centres to supply children under 2 with 80 to $100 \mathrm{~g}$. of full cream dried milk, $50 \mathrm{~g}$. "farina lacteada," made of skimmed dried milk, wholemeal flour and sugar, and $10 \mathrm{~g}$. of cod liver oil daily. In schools and refugee canteens, a daily ration was given of $100 \mathrm{~g}$. 
wholemeal biscuit and $50 \mathrm{~g}$. skimmed dried milk, flavoured with cocoa in the morning and soup extract at night but, as conditions worsened, these quantities were cut by half, and in some areas the children had to be fed only on alternate days.

In some schools in Barcelona a special programme of food, rest and exposure to sunshine was instituted for the ill nourished children under the city education authority. This programme was carried on in the ordinary day schools under the supervision of the usual teachers and required very little additional equipment beyond blankets and mattresses, and no additional personnel beyond that necessary for the heating and serving of milk or a midday meal. The children were divided into three grades according to their physical condition. All children were given $100 \mathrm{~g}$. of skimmed or full cream dried milk supplied by foreign relief organizations, and $100 \mathrm{~g}$. wholemeal bread or biscuit. The most debilitated group of children, group C, spent 3 hours resting out of doors listening to reading by the teacher, gramophone music, and radio talks, and 2 hours in voluntary activities; they were not required to make any effort at concentrating on lessons. Group B had 2 hours lying down at rest outside, 2 hours' lessons, and 1 hour's voluntary activity. Group A followed the normal school routine with an afternoon rest in the open air. This scheme could be extended to all day schools, and it was an experiment in improving conditions for the children without removing them from their family circle.

Experienced bodies, such as the Save the Children Fund, the Society of Friends and the International Commission for War Refugees, are agreed that where a child has a home, the relief policy should strive to make it possible for the child to remain there, rather than to uproot it in the hope of providing better conditions elsewhere (Allied Post-War Requirements Bureau. Technical Advisory Committee on Medical Supplies and Services, 1943). Relief measures should aim at raising the level of nutrition in the whole family and the "day solarium" system just described is more far reaching and economical than the policy of transplanting small numbers of the most debilitated children into colonies. For large scale relief work, the colony system is very wasteful of material and trained personnel, and if, as is usually the case, the most underweight and weakly children are selected, there is a danger of these colonies becoming dumps of the undiagnosed sick, who should more properly be treated through hospital channels. For orphans and abandoned children the colony system may be inevitable as a temporary solution.

In the actual fighting zones and in the final retreat from Catalonia into France, many civilians, especially children, suffered from gastroenteritis from eating uncooked rice, beans and lentils issued from army stores. In the emergency hospital at Le Boulou, on the French side of the Pyrenees, the death rate from gastro-enteritis among children, many of whom were passing undigested beans and rice, was 17 times as great as from war injuries, although the refugees had been bombed and machine gunned all along the route. To tide over the emergency period before civilian relief can be organized, it should be possible for an occupying army to issue simple rations, ready to eat, of the dried milk and biscuit type, supplemented with cheese and chocolate and suitable for all ages.

voL. 2, 1944] 
REFERENCES

Allied Post-War Requirements Bureau. Technical Advisory Committee on Medical Supplies and Services (1943). Provision of Sanatoria and Special Recuperative Measures for Children from 5 to 16. ARB/M/82. (Mimeo.)

Barratt-Brown, M. (1943). Notes on Refugee Camps in the Middle East. (Mirneo. Private.) Friends' Ambulance Unit, 4 Gordon Square, London, W.C.1.

Friends' Ambulance Unit (1944). Notes on Arrangements in an Emergency Camp for Greek Refugees, Syria, Nov.-Dec. 1943, and on the Worl Done by No. 1, $M E F A / M E R R A(F A U)$. (Mimeo. Private.) Friends' Ambulance Unit, 4 Gordon Square, London, W.C.I.

League of Nations (1938). Request of the Spanish Government for the Technical Assistance of the League in the Study of Measures for Providing Food Supplies for Refugees. (Mimeo.) C. 416. M. 261. 1938. VII.

\section{Discussion}

Professor E. Nobel (10 Harley Street, London, W.1), opener: The work which Dr. Russell has described was particularly difficult and complicated because it dealt with more than one category of persons in distress, infants and children, some of them orphans, as well as adults. My experience after the last war was with children only.

In May 1919 the American Government with Herbert Hoover as their representative embarked on a historic task, the mass feeding of malnourished children in the distressed countries of Europe which had been ravaged by the horrors of war.

Austria, prostrate and diseased after the terrible period of destruction, was included in the list of states to be assisted by this unique relief scheme, truly unique, for who could have hoped that, after all the frenzy of hate, the hand of conciliation and friendship would be held out, even before the conclusion of peace, in the supreme endeavour to heal the wounds and bring comfort to the adversary?

What was it that had to be done? Thousands of children and adolescents all over Austria had to be fed daily throughout a period originally limited to 3 months. Pirquet, with whom I had the honour of collaborating, together with a band of Austrian workers, all under American control, undertook the management of the American Relief Organization in Austria, and we had every cause to show our mettle. We succeeded so well that the relief benefits were maintained for over 3 years.

The general arrangement of the food consignments of the American Relief Committee was as follows:

The goods, flour, rice, condensed milk, cocoa, beans and corned beef, which came from America, were brought to Hamburg or Rotterdam from whence they were shipped to Regensburg. The goods destined for the Alpine lands were unloaded in Linz, those for Lower Austria in Vienna. Sugar was purchased by the Americans in Czechoslovakia. Hoover's head offices were in New York, and the general offices for Central Europe were in London. American donations consisted of goods only, and the expenses of distribution were defrayed by Austria herself, with the exception of salaries paid to the few American officials.

The Austrian State paid the charges for freight from the European ports to the Austrian provincial centres, together with those for storage and a contribution of about one penny per meal, known as the State subvention. Forwarding charges from the provincial capitals to the district 
warehouses, and charges for upkeep of the various offices and for supervision, also were covered by a State grant. Expenses for transport from district centres to the different smaller towns and to the individual kitchens were borne by the town councils and to a great part by a small charge made on the children for administration fees. The cooks and kitchen helpers, the kitchen expenses and extras also were paid for from the children's contributions. In cases of great poverty all payments were met by the municipality.

The distribution of food and the preparation of meals was arranged on a uniform plan throughout Austria. The service of meals came under 3 headings:

(1) Public meals in special kitchens, set up, for instance, in former palaces and castles, in hut hospitals and in mobile canteens.

(2) Meals in semi-public institutions such as municipal kindergartens, rest hostels and day nurseries.

(3) Meals in private institutions such as hospitals, orphanages, boarding schools and convalescent homes.

The selection of the children was based on the detection of malnourishment at a medical examination, but the social circumstances of the parents were considered also. One of the governing principles of this act of charity was that the children should reap every benefit without regard to nationality or religion.

The food was distributed only after it was cooked and the whole of the meal had to be eaten on the spot. The greater the number of children fed in this way from the large kitchens, the greater was the assurance that the food would reach the children in conformity with their bodily needs.

The food was allotted according to Pirquet's Nem System, which took as one unit or Nem the nutritive value of $1 \mathrm{~g}$. of milk. The uniform basis for a schoolchild's meal was the nutritive equivalent of 1 litre of milk, representing 667 fully utilized Calories.

The kitchens were managed by women, Nem Damen, who had received a special 2 months' training in the system.

Besides the keeping of books a further check was provided by a special chemical test. Each day a sample dish was taken from one of the large kitchens and its dry weight and fat content were determined and compared with the amounts prescribed in the menu for that day. Similar methods were used in supervising the bakeries.

The assessment of the state of nutrition, the basis on which the food was allotted, was made by determining the Pelidisi according to the Nem System. The Pelidisi is a relationship between the sitting height and the bodyweight which was found empirically to exist, by which in healthy adults, the cube of the sitting height in centimetres is equal to ten times the bodyweight in $\mathrm{g}$. It is only rarely that this relationship will be exactly 1. With the expression for the sitting height as the denominator, the values greater than 1 will indicate overnutrition and under 1 , undernutrition. Actually 100 is used instead of 1 and, from examination of 500,000 schoolchildren, the generalization could be made that individuals with pelidisis below 94:5 are undernourished, from 94:5 to 100 are well nourished, and over 100 are overnourished. The word Pelidisi is made

voL. 2, 1944] 
up from the initial letters of Latin words describing the empirical relationship.

A summary of the state of nutrition was also very easily recorded, for those who understood the system, by making the Sacratama examination. This determined clinically the blood (S) content of the skin, the fat (Cr) content of the subcutaneous tissue, the turgor or tension (T) of the subcutaneous tissue through its water content, and the development of the musculature (M). According to whether these systems were well or poorly developed, different vowels were used in the descending order $\mathrm{i}, \mathrm{e}, \mathrm{a}, \mathrm{o}, \mathrm{u}$ in the word Sacratama, which might become Socretamu or any other combination of vowels according to the individual's state of nutrition. This ingenious method gave a way of recording in a single word the nutritional condition of each of the many thousands of children who had to be examined and kept under observation.

Among the children of Vienna, almost 80 per cent. were malnourished; about 20 per cent. had a Pelidisi of 90 or less, nearly 60 per cent. had one of 90 to $94 \cdot 5$, and rather over 20 per cent. had values over 94.5 . It can be said that without the American relief many thousands of Austrian children would have perished from sheer physical exhaustion or from tuberculosis which finds an easy victim in the debilitated body. It is certain also that many hundreds of thousands were spared the evils and dangers of a stunted growth.

Dr. D. C. Wilson (10 Parks Road, Oxford): The condition of famine at the present time in one province of India, Bengal, is receiving considerable publicity although the chronic starvation always present among large numbers of the population of India has received much less attention.

The interest aroused by Bengal has one advantage in that it leads to the appreciation of the fact that for the relief of famine the provision of food is not enough and that the organization of such relief must be based on adequate knowledge of the societies concerned. Such information can best be obtained by study according to the methods of social anthropology of the social structure of each particular society. Thus, relief has been hampered among the rice eating peoples in Bengal who, though starving, had neither the knowledge nor cooking appliances to make use of the wheat brought to them from northern India, an area where it is the staple cereal of societies of quite a different culture.

Dr. V. Braeuner (Czechoslovak Ministry of Economic Reconstruction, 42 Lowndes Square, London, S.W.1): After the last war, co-operative organizations played a prominent part in securing and distributing supplies of all kinds of merchandise. The collapse of the Austro-Hungarian monarchy brought in its train not only complete chaos in supply and distribution but, to make matters still worse, the disorganization also of the means of transport. By the time the war came to an end, all the stocks of foodstuffs, clothing, footwear, textiles and raw materials were totally exhausted. The people, but especially the workers who had to work very hard under most difficult conditions, were starved of food and suffered from lack of boots and clothing. Women and children were underfed, and nobody knew what the morrow would bring.

It was at that parlous time that the co-operative organizations proved their mettle. The working people had confidence in these organizations, 
both the consumers' and the agricultural co-operative societies. The consumers were fully convinced that these organizations, throughout the war, did all that it was in their power to do. Their services entailed great sacrifices, not on the financial side only, a thing which could not be said of other bodies concerned with supplies for public needs. The cooperative organizations placed at the disposal of the public their powerful and well functioning apparatus of distribution, built up over a good many years by honest toil and possessing thousands of distributing centres in town and country, big storehouses holding thousands of tons of the most varied goods, cold storage for meat, fats and other easily perishable goods, very large modern bakeries for bread and white rolls, big flour mills and many up to date factories for producing soap, vegetable fats and other articles of everyday use. The organizations had thousands of expert, trained men at their disposal, men who had experience of the business of supply. It goes without saying that these organizations, serving as they did the needs of organized consumers, knew best the shortcomings and faults in distribution and, consequently, knew also best how to remove quickly and successfully anything that might prove a handicap to smooth distribution.

Further credit is due to the co-operative movement for the unhesitating way it helped in Czechoslovakia to build for a better future. On the whole, the help we had from abroad was insignificant.

Co-operative distribution has the advantage that it speeds up and cheapens the distribution of goods by conneoting the producer directly with the consumer. The reason why I deal only with co-operative distribution is because I was asked to give a short survey of my experiences in the matter of supply after the last war, and to say how these organizations fulfilled their task. Most decidedly the democratic cooperative organizations proved their worth, as is clearly shown by their tremendous growth after the last war; after the present terrible conflict is over they are sure to be faced with even greater tasks.

As before, so again our organizations are prepared to place at the disposal of the people their experiences and their distributory system, which now is so extensive that it has at its disposal more than 7000 distributing centres; that is to say that with about 15,000 towns and villages in the Czechoslovak Republic, there is a distributing centre in about every second place. The co-operative organizations have about one million members, which means that with the families they supply about 4 million people or 28 per cent. of a total population of 15 millions. In addition, we hope that we shall be able to count on the moral and perhaps also the material help of the International Co-operative Alliance.

Professor A. C. Frazer (Department of Pharmacology, Medical School, Hospitals Centre, Birmingham, 15): It seems probable that relief for large numbers of people will be urgent in the actual fighting zone. It will not be possible for civilian relief measures to be taken in this area. The army will have to organize and run this relief, and it seems most probable that the relief will be inadequate. If this is so there may be some call for specially trained officers comparable with the triage officer in the Field Ambulance, who would carry out rapid examination, and diagnose and classify cases requiring different types of relief according to their urgent needs.

vor. 2, 1944] 
Professor A. St. G. Huggett (St. Mary's Hospital Medical Sehool Praed Street, London, W.2): Professor Frazer has just referred to Dr. Russell has spoken of, Professor Marrack has deplored, the possibility envisaged by Mackenzie (1942), of relief workers having to discriminate by reason of shortage of supplies between those to be relieved and those to starve. Could not a United Nations nutrition strategy be developed by which the English speaking Allies would have a common rationing scheme so that the maximum of food is available for relief on the Continent?

\title{
REFERENCE
}

Mackenzie, M. D. (1942). Medical Relief in Europe. London: Royal Institute of International Affairs.

Professor J. R. Marrack (London Hospital, Whitechapel, London, E.1): The Russians should have considerable experience in feeding civilians in recovered territory. The main problem is one of transport; civilians could be taken back to more settled areas in the vehicles which bring supplies to the troops.

Dr. K. Evang (Royal Norwegian Ministry of Social Welfare, Kingston House, Prince's Gate, London, S.W.7): The food problem cannot be solved by so called "surplus countries," the U.S.A., Canada and Australia, for example, giving away their surpluses. To feed properly the population of the U.S.A. (Stiebeling, 1939) would require the putting of 13 per cent. more land under cultivation. A solution can only be achieved by an increased food production all over the world, internationally co-ordinated.

RefERENCE

Stiebeling, H. K. (1939). Yearb. U.S. Dep. Agric. p. 380.

\section{Opportunities for Nutritional Research in the Work of Relief}

\author{
Miss E. M. M. Hume (Lister Institute, Roebuck House, \\ Old Chesterton, Cambridge)
}

At first it seems rather shocking to contemplate such a thing as research in famine stricken countries but, after the first instinetive recoil, the truly humane individual makes the necessary readjustment, and prepares to consider how, from this boundless loss, some gain may be made. It was done successfully before and it is, therefore, justifiable to consider how it might be done successfully again. There is no doubt that the expedition to Vienna which Dr. Chick led for the Lister Institute and Medical Research Council in 1919-22 secured valuable results which could not have been obtained in any other way (Medical Research Council, 1923). That last qualification is one which needs stressing; the only research which can be regarded as justifiable in these circumstances is a search for results which could not be obtained anywhere else.

If it is accepted that valuable results were obtained from research in conjunction with relief after the last War, it seems profitable to discuss what the conditions were then which yielded success, and how far they are likely to be the same or different in the immediate future. These 
conditions are made up of such a complicated set of scientific and political interrelationships that they do not lend themselves to a simple analysis. The easiest way to deal with them seems to be by sketching the inception and carrying out of last War's investigation, and by exposing the underlying general principles which would be true still at any time. It will then become apparent that the shape of post-war research, hand in hand with relief, will be the same now as before, but that the tempo must be very different; last time workers were unhustled by any comprehensive scheme of relief which would of necessity destroy their research material before they could study it, and were able to act with a comparatively large degree of leisure. This is unlikely to be so in the future.

The end of the last War found the science of nutrition in the English speaking countries developing importantly. In the United States, E. V. McCollum was bringing successive new vitamin factors to birth. In this country the call of the War needs had brought to light much practical new knowledge, and Edward Mellanby was deep in his work with dogs, and battling for recognition of rickets as a nutritional deficiency disease. None of this knowledge had reached our enemies, the Central Empires, and they had not discovered it for themselves. Thus, at the close of the War in 1918, the English speaking countries were full of new knowledge of nutrition, some of it established on a sure basis but much still in need of further confirmation, while our ex-enemies were in ignorance and suffering severely from deficiency diseases through their lack of knowledge as well as their lack of food. In this way the stage was wonderfully aptly set for scientific investigation of this special kind, in Central Europe.

There was no broadcasting of news in those days and it came only slowly. Workers, deeply interested, fidgetted anxiously to know what might be happening in Europe of importance from their particular nutritional standpoint, but it was necessary to wait till paragraphs in the newspapers and vague, unscientific rumours from relief workers began to announce that rickets, scurvy and war oedema were common, and that there were also many cases of a condition which was called adult rickets. This last was the most interesting of all, and leave was granted for a scouting party to set out under official auspices. Dr. Harriette Chick with Dr. Elsie Dalyell as clinician started for Vienna in the autumn of 1919 and the writer joined them in February 1920.

Before the expedition arrived a gap of nearly a year had clapsed since the armistice of November 11th 1918, and yet conditions were improving only very slowly. How different this was from anything that is likely to happen when this war ends! In the secure isolation of ignorance, abundant material for therapeutic trial lay ready to hand. Direct relief was entirely voluntary and was inadequate to cover the whole need and, though it was excellently done by the Society of Friends, the Save the Children Fund and the Amerikanische Kinderhilfsaktion, knowledge only of calories and proximate principles was available to guide it.

We worked throughout hand in hand with the relief organizations and had always, in addition, our own supplies with which to ease our way along, but it did not need much of that sort of easing. Suffering people do not cross examine those who bring them aid, and none of them

voL. 2,1944$]$ 
ever raised any objection. One was much more likely to be informed that one had come in answer to prayer. It is, however, a very important principle that any investigation of this sort should always associate itself as closely and as genuinely as it can with the pure relief organizations. Scientific workers will, in any case, be depriving themselves of one of the deepest pleasures if they miss the surprised gratitude of the unexpectedly relieved sufferer.

At times we, on our side, could help the relief organizations with scientific advice, but our knowledge then was not nearly as definite as now, and the helpful advice which could be given today by scientists working on the spot, at the actual scene of relief, would be cnormous if the relief organizations desired to have it.

Our reconnaissance lasted from September 1919 till June 1920. In the course of it we were able to satisfy ourselves about the condition of adult rickets, the rumour of which had so aroused our curiosity. It proved to be curable with cod liver oil, and occurred in the late winter and spring, except in people not exposed to sunlight in the summer, but it was a true deficiency disease, hunger osteomalacia, and occurred because the food had deteriorated and not because the sky was darkened. It disappeared as soon as food from abroad began to come in, and we could find no more cases for study when we returned in the autumn of 1920 . The people in whom we studied this disease were found in convents, in the biggest general hospital, the Allgemeines Krankenhaus, and in a sick insurance organization for very poor people. The Society of Friends also notified us of cases. It is very important in undertaking work like this to consider how contact is best to be made with the material for study, and where it is to be found. Of the places enumerated above, a hospital is a natural place to look, a sick benefit organization is a likely place since very poor people report sick at it and unsual cases are classified, but a convent is not one of which one would naturally think. The reason the nuns fell victims so readily to osteomalacia was their heavy clothing and their cloistered life, added to their very low living, dictated by their piety as well as by the food scarcity.

Other types of cases for study were obtained at various of the children's hospitals and at a very large national foundling hospital, the Landes Zentral-Kinderheim, which had drawn cases from all over the old Hapsburg Empire. In this last we found children who, through chronic rickets and scurvy, could not sit or stand at 2 years old. Their rehabilitation with cod liver oil and lemon juice then seemed a miracle (Chick and Dalyell, 1921).

All these observations were of a type which it might be expected could be made on a reconnoitring expedition. We searched for any material of nutritional interest and made the best use of it that circumstances would permit in a short time but, all the time, we wore looking for an opportunity to put a particular planned research into execution. The question of the aetiology of rickets was not at all settled. Mellanby's dog experiments appeared to provide quite convineing proof that a vitamin factor was involved but tho school of Noel Paton did not accept this explanation, and ascribed development, of rickets to lack of fresh air and exercise. Perfection of the technique of X-ray photography had recently made it possible to ascertain what was happening to the bone in 
rickets much more exactly than ever before. It was no longer necessary to depend on a clinical examination which could only establish the presence of enlargements and deformities which might not appear till after the rachitic process had begun, and might persist for long after healing had set in, so that exact correlation of the state of the rachitic process with external factors had been impossible. In this improved state of knowledge, what was particularly needed to settle the question of the aetiology of rickets was the opportunity to study radiographically its development in the human infant and its subsequent cure.

An extraordinarily fortunate coincidence of circumstances and personalities gave us this opportunity. The combination was unique and would certainly never occur again though it is not equally impossible that some other, as favourable, constellation might not be created if the opportunity were diligently looked for. The unique personality was that of Clemens von Pirquet, director of the University Kinderklinik which was specially devoted to research. Approach to him was furthered by the distinguished Dutch physician, Professor Wenckebach, who was director of one of the University medical clinies. In the technique of carrying out post-war research in ex-enemy countries, the part which may be played by neutral intermediaries should not be forgotten.

Professor Pirquet was a great organizer as well as a great scientist. His able lieutenant, Dr. Nobel, has already contributed to this meeting. In response to war time needs, Professor Pirquet had elaborated a system for satisfying the nutritional needs of children, as they were then understood, as adequately as possible from the available foodstuffs. Sugar and flour were much more abundant than milk, and the system which Professor Pirquet had established in his Klinik supplied infants with onethird or one-half of their calories as added carbohydrate and the rest as milk. Vitamin supplements were, of course, unknown and not given. Professor Pirquet held no fixed opinion as to the aetiology of rickets, but he was inclined to regard it as due to a low grade infection. Rickets was rife in Vienna and we believed that the dietetic regime at the Kinderklinik was one which would inevitably induce rickets if young babies were maintained for sufficiently long on it.

Here, therefore, was our chance; if we could persuade Professor Pirquet to allow us, for many months, to feed a group of infants in his Klinik, according to the system normally prevailing there, we believed we should have the necessary experiment to produce rickets in human infants. $\mathrm{X}$-ray pictures would be taken every month and, when rickets had been satisfactorily diagnosed radiographically, the condition could be cured with cod liver oil, as we believed, and the fact of cure established, also radiographically. At the same time there would be a group of positive controls protected with cod liver oil.

It seems now almost incredible but, with rare large mindedness, Professor Pirquet agreed to this proposition coming from a group of ex-enemy, foreign women with, it is true, the highest official backing. Without this last nothing would have been possible then any more than now; we could not have obtained our supplies, or ourselves have travelled and been fed.

The experiment was set up on a large scale in the autumn of 1920 ; more than 70 infants, in all, were observed. It would not be profitable voL. 2, 1944] 
now to enter into the many vicissitudes through which we passed. There was, for instance, for a short time a danger from the Municipal Health Authorities when a rumour was put about that foreigners were making experiments with Austrian babies, but any one could come and see how good all the babies looked, much better than if they had remained with their very poor mothers, and the trouble soon died down, never to lift its head again. If, however, the babies had not looked good, it would, and rightly, have been a very different matter.

A further great anxiety was that in the first winter we failed to produce rickets. For a short time we were baffled but we heard, just in time, of the discovery by Huldschinsky $(1919 ; 1919-20)$ that rickets could be cured with ultraviolet light and knew that early spring sursshine on open verandahs had betrayed us.

Still Professor Pirquet was patient with us, and allowed us to continue for another winter and, in that time, we justified ourselves. Many of the babies receiving the diet with carbohydrate addition and no cod liver oil developed unmistakable radiographic rickets, while the positive controls remained free. Unhesitatingly Professor Pirquet acclaimed the result.

This old story has been told in order to show how much was able to be done in even an ex-enemy country; it is true that Professor Pirquet, besides being a quite unbiassed scientist, was a eitizen of the world, a truly international individual, who could not be at home anywhere within the power of the Third Reich. Even if no such internationally minded will to co-operation still lingers hidden in Germany, it will be forthcoming in neutral countries when the time comes.

Although this investigation was so long drawn out, its shape was that of the preliminary reconnaissance or scouting expedition, in which only observations or therapeutic tests could be made, followed by a planned experiment, posing a special question and demanding the maintenance of negative controls. These main lines would be the same today. The earliest expedition must reconnoitre, as before, to ascertain what nutritional diseases are rife, but it would certainly not be necessary to wait for information to be as definite as in 1919 before setting out. Nutritional science is no longer on probation.

Twenty years ago, when we had ascertained what diseases of nutrition were prevalent, our interest was to convince ourselves that the most florid conditions of deficiency really were curable with the specific vitamins. That is much less so now, and interest today is more centred on ascertaining the specificity or otherwise of the less severe symptoms of deficiency disease, and their possible applicability as criteria for assessing the state of nutrition in respect of individual vitamins. For there is still a great deal of uncertainty about the measurement of minor degrees of deficiency, and it is extremely doubtful whether, for instance, some of the changes in capacity for dark adaptation and in the external eye, to which importance has been attached, really have any nutritional significance or not.

This knowledge is very badly needed because enormously high values are being set up for the daily requirement of vitamins, and it is vitally important to know whether such large amounts are really necessary. This question cannot be decided satisfactorily unless minor degrees of 
deficiency can be with certainty identified; there is a reasonable probability that famine stricken countries might provide, for a given deficiency state, a series of pathological changes, well graded from the slight to the severe, in which the slight degrees of deficiency could with certainty be recognized, though there is the danger that multiple deficiencies might obscure the picture. If such clear knowledge of these minor degrees of deficiency could be obtained, it should be possible to define the minimum, and from that the adequate, requirement with greater certainty and, if such very large amounts are not necessary, they should not, as things are, be aimed at; they are very difficult or impossible to provide universally, and their attainment by the fortunate few means even less available for the rest of the world. If they are not really necessary it should be known and a more equitable distribution be secured until such time as there is a real excess.

This is one example of the type of information which it should be possible to obtain, however rapidly and efficiently relief is being done and, certainly, it will be done far more quickly and on a far bigger scale than in 1920. This particular knowledge too is exactly the kind of information which will be most valuable to those having the relief to do, since the scientists and clinicians collecting such data will be able to indicate better than anyone else how severe and widespread the different nutritional deficiencies are.

Whether, as war recedes, there will be any scope for the planned experiment is much more doubtful. There are undoubtedly other problems, such as those of anaemia and war oedema, for whose study there might be an opportunity. The justification for carrying out in difficult circumstances such a planned experiment as was made in Vienna is the possibility, unattainable in any other way, of providing an adequate negative control. This demands the existence of a number of cases which persist untreated through ignorance, or through the insufficiency of relief material, or for which relief is officially deemed not necessary. Negative controls which it would have been inhuman to try to provide may even appear after the experiment is over. This happened in one remarkable instance after we had treated the backward children to whom reference was made earlier, children who, through chronic rickets and scurvy could not sit or stand at 2 years old. One little girl, Ida Potharany, had been brought back to active life with cod liver oil and lemon juice, and we were just winding up our work in that ward when our Austrian colleague in charge of the ward told us that, in another ward to which we had never had access, Ida Potharany had a twin brother whose state was as deplorable as hers had been. The Austrian doctor connived at our getting a picture and Ida and Johann Potharany met surreptitiously to be photographed together. A more perfect negative control could not easily have been devised although it was purely accidental, but it needed swift decision and swift action to snap it up. The existence of the negative control in this case may have depended partly on the ignorance of vitamins which walled the Central Empires in but was due chiefly to the inadequacy of the relief materials available for distribution.

There is not much likelihood today that ignorance will provide a supply of negative controls and it is greatly to be hoped that inadequacy of relief will not do so either. Nevertheless, if there are problems to voL. 2, 1944] 
which an answer could be obtained only in these circumstances of qualitative or quantitative famine, they should be borne constantly in mind by anyone undertaking a reconnaissance, and any opportunities for working them out should be utilized.

The conditions in which countries will be freed and the season of the year at which it will happen are so completely unknown to scientists that it is impossible to be anything but vague about the future, and no cut and dried plan can be made. Perhaps there will be scope for our alleged national gift of improvisation; certainly our attitude should be that of alert expectancy. Perhaps past experience may be some guide, and there are two fundamental rules which should never be forgotten by any person undertaking research in countries in process of relief and rehabilitation. The first rule is that the only work of the kind which it is justifiable to do is work which could be done nowhere else, and the second rule is that the research workers should acquire the habit of regarding themselves with the eyes of the local civil and military administrators so that they see themselves only as a nuisance, and humble themselves accordingly.

\section{REFERENCES}

Chick, H. and Dalyell, E. J. (1921). Brit. med. J. 1921, ii, 1061.

Huldschinsky, K. (1919). Dtsch. med. Wschr. 45, 712.

Huldschinsky, K. (1919-20). Z. orthop. Chir. 39, 426.

Medical Research Council (1923). Spee. Rep. Ser. med. Res. Coun., Lond., no. 77.

\section{Discussion}

Dr. A. P. Meiklejohn (Oxford Nutrition Survey, 10 Parks Road, Oxford), opener: Miss Hume has given a very realistic account of the important research which she and her colleagues were able to carry out amidst the distressing conditions prevailing in Vienna after the last war. Perhaps we should do well to remember the indirect consequences of this classic work. Today the health of thousands of young children throughout this country is protected by cod liver oil and fruit juice provided for them by the Ministry of Food. This provision with which our Chairman has been closely associated, is certainly a most outstanding and fundamental achievement in public health administration.

Miss Hume has indicated the practical problems and difficulties that were encountered by research workers in Europe after the last war. As she rightly says, many of these practical issues are likely to arise again. Those responsible for their solution should benefit by this previous experience. But, if I may disagree with Miss Hume for a moment, I do not think that the shape of post-war research will be the same this time. It is not the tempo only that will be different. The important difference is that the whole science of nutrition has made immeasurable strides since the last war. Many of the vitamins for instance whose very existence was dubious 25 years ago, are now not only isolated, but also being synthesized in large quantities. Furthermore there is now a most extensive and useful knowledge of the part played by these and other nutrients in the maintenance of normal health in the human body. The successful application of this new knowledge of nutrition to the problems 
of post-war relief may require that kind of wisdom which "lies in masterful administration of the unforeseen".

We have just heard about one type of research, the controlled feeding experiment, which, as Miss Hume says, is only possible when relief measures have broken down, and justifiable only when the information needed can be obtained in no other way. I would like to lay emphasis on the other type of research, which Miss Hume has mentioned under the term reconnaissance. I will not quarrel with this term, provided that it implies reconnaissance in strength. The important new development is that knowledge of human nutrition has now reached the point where teams of trained investigators can go out and bring back in a relatively short space of time a scientifically acceptable assessment of the state of nutritional health of samples of the population. Such teams require the combined knowledge and experience of doctors, biochemists and dieticians. The method has already undergone successful trial in several places in North America and more recently in this country.

Briefly, the procedure of such teams is as follows: Families are selected by one of a number of methods available for random sampling, and are asked to attend at a suitable medical centre. Each member of the family is examined for clinical defects known to occur commonly in malnourished subjects. A clinical history is also taken for symptoms suggestive of nutritional deficiency. A sample of blood is obtained, from at least the adults, for the estimation of haemoglobin, plasma protein, plasma vitamin $\mathrm{C}$ and, if possible, other nutrients. The eyes are tested for dark adaptation to detect any night blindness due to vitamin A deficiency. From this information it is possible to place the subjects into one of three categories:

(1) Those who are obviously in excellent health;

(2) Those who are definitely malnourished;

(3) Those whose intermediate state of nutrition cannot be determined with certainty with the knowledge at present available.

After this examination a dietician visits the home or living place of the family to find out about the foods obtained and the socio-economic circumstances of the family. From all this information it is possible to obtain a very precise idea of the extent of malnutrition and underfeeding in the community and also, what is more important from a practical point of view, the dietary, social and economic factors responsible.

The information which such teams could provide in post-war Europe should be invaluable to those concerned with the administration of relief. It would show which types of food are most urgently needed so that the best possible use could be made of the limited transport facilities likely to be immediately available. Relief should no longer be guided by little more than guesswork, or by "vague, unscientific rumours" which were all the Lister Institute mission to Vienna had to go on. It is worth remembering that famine relief unguided by any scientific principle may fail partly, or even wholly, in its object; for instance, when American maize was imported for the relief of the Irish potato famine, symptoms of pellagra were added to the scurvy that already existed.

I have stressed the immediate practical value of observational research. vor. 2,1944$]$ 
But in the course of such work there will obviously be incidental opportunities for adding to existing knowledge of human nutrition. I entirely agree with Miss Hume that out of the grim experience which lies before us it may be possible to learn a great deal more about the early clinical manifestations of specific dietary deficiencies. This may later prove invaluable in times of peace for detecting with certainty the first effects of a faulty diet.

Perhaps it is not too fanciful to view the whole question of future European relief as a vast and desperate experiment in human nutrition, on a scale never before attempted and which, we must hope, will never be needed again. One outcome of this experiment should be a more exact definition of the dietary needs of man, first to restore health and then to maintain it. As Miss Hume has implied such knowledge will be vitally needed in planning the proper distribution of the world's supplies of food. The success or failure of this experiment may depend, in large part, on the understanding and co-operation of scientific observers on the spot with those responsible for the administration of relief.

Dr. S. Joles (Health Department, Dutch Government, Arlington House, London, S.W.1): There is need for a study of the relation of jaundice to starvation and to protein deficiency.

Dr. L. M. Kerly (University College, Gower Street, London, W.C.1): A study of optimum intake of main nutrients might be conducted during the period in which rationing must still be maintained.

Dr. H. M. Sinclair (Oxford Nutrition Survey, 10 Parks Road, Oxford): $I$ have just returned after spending nearly 3 months in the U.S.A. and Canada, during which time I have had the opportunity of discussing the question of nutritional relief with many people. Miss Hume, discussing research, said the earliest expedition must reconnoitre; and Dr. Hammond discussing the public health aspects, said that observers should be early in the field. Therefore nutritional surveys made either for public health purposes or for scientific research can be considered together. The need for such surveys is obvious because the main problem is to make the best use of the limited supplies of food and of nutrients. Dr. Evang wisely reminded us that we must not speak of surpluses of food; it is well to remember that the U.S.A. has more malnutrition than we have in this country, and what food they send is a generous sacrifice on their part. There is no general surplus of food in the U.S.A., and they tend to abandon the word and to speak of "local abundances". instead.

I do not see why Dr. Evang wishes to abandon the word AMGOT; perhaps he would prefer SPAMGOT, for some military organization must distribute the American food. And that raises a very important question that has not been discussed at all: under whose auspices are nutritional surveys to be made? It is obvious that the Army will rightly be in control of released territory during the first 6 or 9 months, and presumably it will only countenance work that is essential for the prosecution of the war. Pure research does not come into that category; but the proper distribution of food and, if need be, of nutrients is essential for the health and the morale of the people the Army liberates. Therefore rapid nutritional surveys should be made, by teams in uniform and under military auspices, as soon as possible after military occupation to define 
the immediate epidemiological problem. Such surveys might well come under a Nutrition Commission, similar perhaps to the Typhus Commission.

Then, later, more detailed studies can be made, under the auspices of UNRRA and, later still, a permanent nutritional organization should be left in the hands of the public health authorities of the liberated country.

In such surveys full collaboration with the national doctors and nurses, agriculturists and nutritionists is essential. In fact, one of the main functions of the survey teams we hope to provide will be to bring the latest tools for assessing the state of nutrition to the liberated countries and to help them to use those tools. Then the limited supplies of food will be distributed in the best way, and special nutrients directed to the places where they are most needed.

Mr. A. L. Bacharach (Glaxo Laboratories, Ltd., Greenford, Middlesex): Thought should be given to the problem of co-ordinating the relief measures that will necessarily be undertaken by AMGOT or other Army organization during the essential period of military occupation and by UNRRA subsequently, so that investigations, whether of the reconnaissance or the more specific type, are not rendered abortive by complicating factors or the elimination of negative controls. The time for arranging the necessary liaison between investigators, the civilian relief organizations and the Army authorities is now. All teams sent to carry on scientific investigations in places where food relief is being administered must, in view of the complexity of the problem, include one member with adequate knowledge of modern statistical methods.

Dr. F. Bicknell (79 Wimpole Street, London, W.1): Research on the relationship of the vitamins to each other would be easy and justified during the work of relief and would help to decide whether single vitamins or combinations of them should be used in clinical medicine.

Professor A. St. G. Huggett (St. Mary's Hospital Medical School, Praed Street, London, W.2): Pregnancy imposes special nutritional strains and is fraught with more unsolved physiological problems than any other phase of human life. Hence observations of the state of health and nutrition of pregnant women can be used as a sensitive index of the adequacy of the food supply of a population.

Dr. E. Kodicek (Dunn Nutritional Laboratory, Cambridge): More elaborate methods than those mentioned by Dr. Meiklejohn may be used in nutritional research, especially saturation tests for various vitamins. These, however, require equipment which may not be available to workers in the field. They could be made possible by collaboration with universities and research institutes in the liberated countries which should be helped to re-equip their laboratories.

Miss E. M. M. Hume:

In reply to Dr. Meiklejohn: It would seem desirable to emphasize that some of the criteria, on which reliance is placed for assessing nutritional status in respect of vitamins, are themselves still in need of further vor. 2,1944$]$ 
investigation, and would not afford a really satisfactory basis for nutritional surveys to estimate need in connexion with distribution of famine relief.

\section{Chairman's Summing up}

The Rt. Hon. Lord Horder (141 Harley Street, London, W.1): There are perhaps four aspects upon which we have touched today and I would personally like to say that it has not been without some satisfactory results that this Conference has been held. As I was asked to do, and as I thought it was wise to do, I warned you that we should confine ourselves to the scientific and clinical aspects of this matter. I did not think that we should succeed in achieving this isolation of the academic issues involved from the political and economic aspects, nor have we succeeded very well. We need not be apologetic. It is, as with most of these large questions, not only a medical problem. It is social and it is administrative. That is an inevitable conclusion, because even our distinguished visitor from Norway could not himself dissociate the medical problem from the economic political aspects towards which, by the way, he made some very pungent and constructive remarks, reminding us for instance that our American friends are reasonable in saying that to transport surplus foods to occupied Europe is not the solution of the nutritional problem. It must be, as Dr. Evang and others have said, Dr. Hammond particularly, that we continue our efforts in the most intensive manner that we can to keep our production at a high level. To continue, in other words, what we do think that the present Minister of Agriculture has made a good effort to carry out.

There are four points I want to summarize or epitomize, four aspects to touch upon: (1) The size of the problem; (2) the question of supply; (3) the organization in the field; (4) the relation which this Society bears to the whole problem, viz., research, observation and experiment in relation to the unique opportunity which presents itself.

(1) The Size of the Problem. Professor Marrack made it clear that we must not underestimate the extent and depth of the problem. It is larger than the majority of people in this country think. There is educational value in a Conference of this kind, if it can be used without offending the susceptibilities of those who think social medicine should be a hush-hush affair; to me social medicine and hush-hush are incompatible. We do want to emphasize the enormous area of the occupied territories as compared with the extent of them last time. Dr. Marrack referred to the lag which occurred last time and will inevitably do so this time, the lag in local production within the occupied countries, and in imports to the occupied countries. He said that in 1921 there were still signs of malnutrition in children.

(2) The Question of Supply. Dr. Hammond thought that the minimum requirement was to be the foundation on which supplies should be based but, when he came to deal with the thorny problem of what is the minimum requirement, I did not find the answer. If todays's ration is to be regarded as the basis of minimum requirement, our ration, not the ration in occupied countries, that is rather disappointing to me, because I was hoping that, both as a gesture and as a contribution to the food shortage, we might consider whether we could not do with less, even for a few months. 
I must not take that much further if we are to regard the present Ministry's ration as getting us near to the ration to which Dr. Evang referred, concerning which he said it would be so valuable if we had a sign, clinical or otherwise, that a human being is about to enter the nutritional danger zone. We are all waiting for that, that is what The Nutrition Society is for.

On this question of our ration, there is more than the civilian ration to consider if we are asking ourselves what can we do other than we are doing. There are the fighting services; the strain will be less, they will be less mobilized and the question of the feeding of the fighting services may be brought under survey. I have had the diet sheets of the.services under survey at various times, and have gone home to my own meagre rations with envy at not myself being a fighting unit and, when we consider the numbers of the fighting men and women today, there should be some saving there. Then there are the priority rations for heavy industrial workers. Will they always want to gorge these large amounts of protein? I suggest there may be some saving possible there. There must also be some intensified increase in home production by the means Dr. Hammond detailed.

(3) The Organization in the Field. I have no comment to make on field surveys of the past, except to take my hat off to Dr. Harriette Chick and Miss Hume for what they did last time.

(4) Research, Observation and Experiment. Perhaps it was pardonable that Miss Hume should speak of it being a little shocking to do research on malnourished citizens. She realized that that was not quite the right thing to say, and Dr. Meiklejohn reinforced her, if she needed any reinforcement, when he said that there were, with the enormous amount of new material and new knowledge, new eriteria with which to make observations. These are two very vital points. When experiments of this kind are made, we come along with newer powers of observation and newer facts to guide us. The tempo of the research is more likely to be speeded up to help the nature of the research we are doing. In the first instance it must be food for first aid, and in that period even observations, still more planned research, will not be very practicable. At the second stage, when the first aid stage is over, then surely there will be ample opportunity, and I think the travelling part of The Nutrition Society will bring home quite a number of very valuable new facts in connexion with nutrition: I was glad that Dr. Sinclair touched upon what I might call still a third stage, AMGOT. The sooner it is over the better, we think. AMGOT must do a lot of good work. HUHO, which means help us to help ourselves, is to me vital. We should not talk down to people, still less should we work down to them. We do not want to tip food into other countries. We want to give them first aid to bring them to a stage when they have become stabilized and then to let them get on with it. They may have more to say about their own conditions than we have and they may carry out some research of their own. Let us help them to feed themselves even from the moment that the military organizations have gone home. 